\title{
Para uma crítica da razão socioeducativa em entidades assistenciais ${ }^{1}$
}

\section{Towards a critique of "socio-educational" rationality in welfare entities}

\author{
Silvio José BENELLI² \\ Abílio da COSTA-ROSA ${ }^{2,3}$
}

\begin{abstract}
Resumo
Buscou-se cartografar as instituições de assistência social que atendem à infância e à adolescência consideradas em "situação de risco pessoal e social", em um município do interior do estado de São Paulo, utilizando o instrumental da análise institucional. O papel de membro do Conselho Municipal dos Direitos da Criança e do Adolescente e do Conselho Municipal de Assistência Social facultou a realização de uma análise documental nos arquivos desses Conselhos, relativa às entidades assistenciais cadastradas, tais como organizações governamentais, organizações não-governamentais e outros estabelecimentos filantrópicos. Os resultados indicam que, no universo da Assistência Social, a constelação criança/adolescente orbita em torno do astro-rei "socioeducativo". Todas as atividades desenvolvidas nas entidades parecem recobertas por esse significante-mestre, que conota dimensões pedagógicas e terapêuticas, educativas e corretivas, de vigilância e de prevenção, promovendo controle e normalização.
\end{abstract}

Unitermos: Adolescentes. Análise institucional. Crianças. Políticas públicas. Psicologia social.

\begin{abstract}
We set out to map the social welfare institutions that care for children and adolescents considered to be at "social and personal risk" in a town in the state of São Paulo, using a set of institutional analysis tools. Our role as a member of the Municipal Council of Children's and Adolescents' Rights and of the Municipal Council for Social Welfare permitted an analysis to be carried out of the documents in the archives belonging to these councils, in respect of registered charities, such as governamental organization, non-governamental organization and other charitable institutions. The results indicate that, in the universe of Social Welfare, the "child/adolescent constellation" orbits around the "socioeducational" star-king. All activities in the entities seem to be covered by this "master signifier" that predicates dimensions that are pedagogical and therapeutic, educational and corrective, surveillance and prevention related, promoting control and standardization.
\end{abstract}

Uniterms: Adolescents. Institutional analysis. Children. Public policies. Social psychology.

\section{$\boldsymbol{\nabla V} \mathbf{V}$}

1 Este artigo é parte da pesquisa de Pós-Doutorado "Cartografia das instituições de assistência social a crianças e a adolescentes", desenvolvida pelo Dr. Silvio José Benelli, sob a supervisão do Prof. Dr. Abílio da Costa-Rosa, Universidade Estadual Paulista Júlio de Mesquita Filho, Faculdade de Ciências e Letras. Apoio: Fundação de Amparo à Pesquisa do Estado de São Paulo.

2 Universidade Estadual Paulista Júlio de Mesquita Filho, Faculdade de Ciências e Letras, Curso de Psicologia, Departamento de Psicologia Clínica. Av. Dom Antonio, 2100, Parque Universitário, 19806-900, Assis, SP, Brasil. Correspondência para/Correspondence to: S.J. BENELLI. E-mails: <sjbewelli@yahoo.com.br>; $<$ benelli@assis.unesp.br>.

3 Universidade Estadual Paulista Júlio de Mesquita Filho, Programa de Pós-Graduação em Psicologia. Assis, SP, Brasil. 
A interface da Psicologia com a Assistência Social no campo das políticas públicas tem recebido atenção crescente do Conselho Federal de Psicologia (www. pol.org.br), que já realizou diversos seminários sobre o tema e também criou um Centro de Referência Técnica em Psicologia e Políticas Públicas (CREPOP). Também produziu referências técnicas para o trabalho do psicólogo e do assistente social, no campo da Assistência Social na atualidade (Conselho Federal de Serviço Social, 2007). O CREPOP (http://crepop.pol.org.br) tem como objetivo sistematizar e difundir o conhecimento e as práticas psicológicas aplicadas ao setor público estatal do mercado profissional. Trata-se de um espaço de pesquisa, produção de referência e articulação política das várias áreas de atuação da categoria dos psicólogos, em políticas públicas nos níveis municipal, estadual e federal.

O campo da Assistência Social como política pública está se abrindo como uma importante frente de trabalho, intervenção e pesquisa pelos profissionais da Psicologia. A divulgação de informações e a capacitação nessa temática são importantes tanto para alunos de Psicologia quanto para profissionais da rede socioassistencial, visando contribuir para uma inserção crítica e transformadora nesse âmbito da realidade. Atualmente os psicólogos estão cada vez mais envolvidos com trabalhos em entidades assistenciais e em diversos dispositivos que implementam políticas públicas em múltiplos setores: infância, adolescência, famílias, idosos, deficientes, saúde etc., tanto no âmbito federal quanto no estadual e municipal. É fundamental que esses profissionais tenham conhecimento da problemática mais ampla que envolve a Assistência Social e seus temas conexos no país (Conselho Federal de Psicologia, 2003, 2005, 2007a, 2007b; Conselho Federal de Serviço Social, 2007; Centro de Referência Técnica em Psicologia e Políticas Públicas, 2007; Cruz \& Guareschi, 2009).Este relato é parte de uma investigação que pretende oferecer uma contribuição crítica aos psicólogos que trabalham nesse campo em particular.

Este artigo justifica-se ao problematizar criticamente o modo de funcionamento das entidades socioeducativas no campo da Assistência Social, pois é preciso ter coordenadas claras numa área complexa e nebulosa, para que a intervenção seja efetivamente ca540 paz de promover a busca do equacionamento dos problemas sociais de modo crítico, ético e dialético. Acredita-se que a implicação ética e política é importante na atuação dos profissionais da Psicologia, pois suas práticas são dispositivos de produção de subjetividade (Benelli, 2009; Paiva \& Yamamoto, 2010).

Buscou-se uma visada que parte dos antípodas de uma certa glamourização da pobreza - operação que procura embelezar os pobres de todas as idades - buscando transformá-los em produtos com valor agregado, palatáveis ao gosto do mercado, que anda faminto para lucrar com a Responsabilidade Social Empresarial por meio do marketing social (Benelli \& Costa-Rosa, 2010; Montaño, 2007). A intenção também incluiu uma superação de todo e qualquer traço de benemerência filantrópica desenvolvida por parte da elite que, em sua hegemonia pragmático-preventivista, procura "inocentemente" fazer o bem aos mais pobres, enquanto exerce um férreo controle sobre eles, que permanecem eternamente dependentes e à mercê da ajuda, muitas vezes irrisória, que recebem (Donzelot, 2001; Foucault, 1999; Marcílio, 1998; Rizzini, 1997; Saliba, 2006). Também se procurou fugir ao lugar comum que tende a predominar no discurso oficial do poder público - longamente conhecido durante a participação em conselhos municipais - normalmente eivado de um cínico clientelismo assistencialista e eleitoreiro (Santos, 2001; 2002). Questionou-se ainda uma série de saberes ditos científicos (Baremblitt, 1998, Foucault, 1999; Santos, 2000, 2004), tanto da psicologia, da pedagogia e da sociologia quanto da política, que, entre insípidos e alienados, estão sendo implementados cotidianamente e configurando uma prática de atenção socioeducativa que oblitera completamente a condição de cidadãos - enquanto sujeitos de direitos e desejos - de crianças e adolescentes pobres.

Esta pesquisa foi realizada a partir de um pano de fundo teórico-técnico, político e ético fornecido pela Análise Institucional (Baremblitt, 1998; Barus-Michel, 2004; Costa-Rosa, 2000, 2006; Foucault, 1999; Goffman, 1987; Lourau, 1995), pelo pensamento foucaultiano e também pelo instrumental teórico de Costa-Rosa (2000; 2006), visando a um posicionamento analítico e crítico, num campo composto por entidades assistenciais que atendem crianças e adolescentes considerados em "situação pessoal e social de risco" num município do interior do estado de São Paulo. Essas instituições desdobram-se em estabelecimentos assistenciais que 
condensam uma lógica de funcionamento que articula normas legais e atores institucionais, num processo de produção social cujos resultados convém analisar.

A atuação implicada como membro do Conselho Municipal dos Direitos da Criança e do Adolescente (CMDCA) e do Conselho Municipal de Assistência Social (CMAS), permitiu uma experiência de imersão intensa no campo e proporcionou um conhecimento minucioso dessa realidade. Também foi realizada uma análise documental nos arquivos desses Conselhos, relativa às entidades assistenciais voltadas para o atendimento de crianças e adolescentes, tais como Organizações Governamentais (OG), Organizações Não-Governamentais (ONG) e outros estabelecimentos filantrópicos. A condição de conselheiro permitiu acesso livre à documentação pertinente e também às instituições assistenciais, tornando essa pesquisa plenamente exequível. Foi a partir desse lugar privilegiado que se realizou a presente pesquisa. Também se buscou obter as autorizações formais a quem de direito para a realização das investigações, por meio de termo de consentimento esclarecido, dentro dos padrões éticos da pesquisa psicológica.

Benelli (2004, p.250) afirma que:

Muitas questões pedagógicas, psicológicas, psiquiátricas, hospitalares, da saúde coletiva, etc., podem se tornar mais inteligíveis quando enquadradas num marco institucional global. Entendemos que os problemas institucionais são também problemas sociais. Soluções técnicas muitas vezes não são suficientes para resolvê-los. Eles exigem soluções políticas para sua metabolização. A política não é uma questão técnica (eficácia administrativa) nem científica (conhecimentos especializados sobre gerenciamento ou administração), é ação e decisão coletiva quanto aos interesses e direitos do próprio grupo social.

Portanto, estudar as instituições assistenciais envolvidas com o atendimento de crianças e adolescentes considerados em "situação pessoal e social de risco", nesse município, constitui uma oportunidade de construir um saber relevante para a área das políticas públicas voltadas para esses atores sociais. Trabalha-se com a hipótese de que o reconhecimento, mesmo cognitivo, da especificidade da constituição e funcionamento das instituições assistenciais dedicadas a atividades socioeducativa com crianças e adolescentes, bem como das suas vicissitudes mais correntes, pode funcionar como um importante operador de análise e compreensão. Esse reconhecimento seria capaz de funcionar como um bom ponto de partida para a construção de encaminhamentos para os diferentes impasses que impedem as soluções mais adequadas aos problemas da clientela, e que também costumam traduzir-se em sofrimentos laborais nos diversos atores institucionais. As determinações sócio-históricas e institucionais também possuem um caráter dialético, pois, ao se tomar conhecimento das suas contradições, é possível operar ativamente sobre tais determinantes e modificá-los (Costa-Rosa, 2000; 2006). Visa-se, assim, fornecer aos gestores públicos (Secretaria Municipal da Assistência Social, Juizado da Infância e Juventude, Conselho Tutelar, Conselho Municipal dos Direitos da Criança e do Adolescente, Conselho Municipal de Assistência Social) e às próprias instituições assistenciais, dados orientadores relevantes para a implementação de políticas mais efetivas voltadas para o atendimento da infância e adolescência no município.

\section{Parâmetros de investigação e análise}

Para estudar a multifacetada realidade que constitui a Assistência Social a crianças e adolescentes, e as entidades que a implementam, necessita-se de uma abordagem também complexa. A perspectiva teórica adotada pautou-se na Análise Institucional (AI) (Baremblitt, 1998; Barus-Michel, 2004; Costa-Rosa, 2000, 2006; Foucault 1999; Goffman, 1987; Lourau, 1995), que permitiu realizar uma pesquisa transversal transitando por diferentes campos de saberes e práticas sociais: saúde, educação não formal, pedagogia, assistência social, direito, justiça, psicologia social, pensamento institucionalista e também foucaultiano, por meio da revisão da literatura, procurando cartografar o modo de funcionamento dos estabelecimentos assistenciais socioeducativos, que foram visitados e conhecidos. 0 estudo foi aprovado pelo Comitê de Ética em Pesquisa da Faculdade de Ciências e Letras - Unesp/Assis, protocolo n 030/2008, em 30 de outubro de 2008, tendo todos os participantes assinado um Termo de Consentimento livre e esclarecido antes de sua inclusão na amostra.

A análise institucional é uma prática que se insere no movimento institucionalista (Baremblitt, 1998). O objetivo de conjunto dessas tendências é propiciar e 
apoiar processos de autoanálise e autogestão dos coletivos sociais: comunidades, grupos, instituições etc. Foram utilizados alguns recursos teórico-técnicos da análise institucional: o campo de análise permitiu delimitar um objeto ou um campo e aplicar-lhe o aparelho conceitual da análise institucional para entendê-lo, para saber como funciona, como estão colocadas e articuladas suas determinações e causas, e como se geram seus efeitos. $O$ analisador institucional (Baremblitt, 1998; Lourau, 1995) foi outra ferramenta importante para a pesquisa. Ele não precisa ser constituído de material verbal; pode ser um monumento, uma planta arquitetônica, um arquivo, uma distribuição do tempo ou espaço na organização. Sua materialidade expressiva é totalmente heterogênea. Ele sempre é analítico em si mesmo, contendo elementos para se autoentender, para começar o processo de seu próprio esclarecimento e de transformações institu-cionais. Seu processo e produto podem ser estudados.

Os analisadores podem ser históricos, quando são produzidos na história e no próprio contexto da instituição analisada, mas também podem ser construídos, inventados com o objetivo de explicitar os conflitos e resolvê-los. Em diferentes momentos da constituição de um campo de análise, é possível a realização de vários tipos de diagnósticos, sempre provisórios, da estrutura, da dinâmica, dos processos, das contradições principais e secundárias - indicando se tais contradições são diferenças meramente opositivas ou se constituem diferenças antagônicas (contraditórias no sentido dialético); indicando a natureza e o estado dos conflitos, das defesas, das magnitudes de produção, reprodução e antiprodução; em suma, indicando a operatividade dos analisadores, a composição momentânea dos territórios instituídos e das linhas de fuga da instituição estudada.

O institucionalismo afirma que a sociedade é um tecido de instituições (Baremblitt, 1998). As instituições, segundo o grau de formalização que adotem, podem ser leis, normas ou regularidades de comportamentos. São exemplos: a linguagem, as relações de parentesco, a educação, a religião etc. As instituições se materializam em dispositivos concretos, as organizações, que por sua vez se compõem de unidades menores, denominadas estabelecimentos. Os estabelecimentos costumam incluir dispositivos técnicos: as instalações materiais, maquinaria, arquivos, aparelhos. Esse con- junto de elementos recebe o nome de equipamentos. Todos esses elementos - instituição, organização, estabelecimento, equipamento - adquirem dinamismo através dos agentes (atores institucionais), os sujeitos que são os suportes e protagonistas da atividade coletiva microfísica responsável pela substância da instituição. Os atores institucionais protagonizam práticas sociais que podem ser verbais, não verbais, discursivas, teóricas ou técnicas.

É possível distinguir duas dimensões fundamentais das instituições: o plano instituinte (processo dinâmico, dialético) e o plano instituído (produto) (Baremblitt, 1998). Instituinte remete ao conjunto de forças que tendem a fundar instituições, momento fundacional original, e atualiza-se constantemente como processo ou movimento criador e dinâmico, que mantém a instituição viva e sempre renovada, atualizada, transformada e em transformação. Instituído seria o resultado material dessa força instituinte. Para entender uma instituição, é preciso ter em mente que os instituídos, os organizantes-organizados que constituem a rede social, e a dimensão instituinte, não atuam separadamente, mas se interpenetram em vários níveis. Convencionou-se chamar atravessamento à interpenetração do nível reprodutivo, conservador, enquanto a expressão transversalidade designa o movimento de interpenetração do instituinte, do criativo, do novo (Baremblitt, 1998). Convém assinalar que, para a Análise Institucional, o instituinte vai muito além daquilo que se contrapõe de modo articulado ao instituído, no campo das chamadas contradições dialéticas; ele compreende todo um campo de pulsações que ainda não passaram pela mediação ideológica e imaginária, e que podem escapar a elas, funcionando como linhas de transformação dinâmica do campo institucional com seus diversos componentes. Uma análise complexa deve articular esses dois planos das relações entre instituído e instituinte.

Os dados do presente estudo foram obtidos através de uma participação observante e reflexiva no amplo campo de análise composto pelas entidades assistenciais enquanto conselheiro municipal, e também por meio da análise documental. Foram estudados e analisados os documentos das entidades assistenciais arquivados nos Conselhos Municipais, com base no conhecimento concreto das suas especificidades, procurando-se detectar quais são seus referenciais teórico-metodológicos, os aspectos administrativos e fun- 
cionais da equipe gestora, bem como qual a concepção política do projeto socioeducativo. Com relação ao atendimento institucional à criança e ao adolescente na proteção social básica, trabalhou-se com a hipótese de esse atendimento a uma clientela considerada em "situação pessoal e social de risco", consistiria num plano transdisciplinar, operado por equipes multidisciplinares compostas por dirigentes, educadores sociais e técnicos administrativos.

Da composição desse plano, entende-se que fazem parte saberes e práticas da Educação e da Pedagogia (Cotrim,1993; Francisco Filho, 2004; Libâneo, 1994; Saviani, 1988), da Psicologia (Benelli, 2009; Bock, Gonçalves \& Furtado, 2002; Bujes, 2000, 2002; Bulcão, 2002; César, 2008; Coimbra, Bocco \& Nascimento, 2005; Cruz \& Guareschi, 2004, 2009; Cruz, Hillesheim \& Guareschi, 2005) e também da Assistência Social (Costa, 2006; Diniz \& Lobo, 1998; Donzelot, 2001; Rizzini, 1997), da Saúde, da Justiça e da Segurança Pública (Monteiro, 2006; Nogueira Neto, 2010; Saliba, 2006). Há um importante plano jurídico e legal instituindo a realidade social de crianças e adolescentes, inclusive produzindo todo um aparato institucional composto por leis, por estabelecimentos e por práticas sociais relacionadas com tais figuras. Certamente pode-se ainda entender que há também uma dimensão cultural que tende a conceber e a lidar com crianças e adolescentes de modos diversos. Procurou-se problematizar esses campos de saberes e de fazeres, que são compreendidos como configurando as práticas denominadas "socioeducativas", esboçando-se também alguns apontamentos críticos sobre os objetos/sujeitos dessa ação institucional: as crianças e os adolescentes na contemporaneidade.

Para análise e interpretação de dados da experiência de campo, bem como dos coletados por meio de estudo documental, utilizou-se uma grade analítica de base lógico-histórica e de inspiração marxista dialética, criada por Costa-Rosa (2000; 2006). O instrumental foi utilizado para mapear paradigmas contraditórios num determinado campo de análise (o da saúde mental pública, por exemplo, ou o das instituições assistenciais); para compreender suas mútuas relações; e para articular os temas da produção institucional quanto a seus processos designados como tais e quanto aos processos simultâneos da produção de subjetividade. Costa-Rosa propõe quatro parâmetros mínimos como definidores de determinado paradigma de produção institucional num determinado campo de análise: a) concepções de "objeto" e dos "meios" de ação junto a ele; b) concepções das formas de organização do dispositivo institucional; c) modos da inter-relação entre a instituição, a clientela, a população e o território e população-instituição; d) concepções dos efeitos terapêuticos (educativos, socioeducativos, pedagógicos) e seus desdobramentos éticos. Esse instrumental já se mostrou útil para análises institucionais nos campos da psicologia, da educação e da religião católica (Benelli, 2006a, 2006b, 2007; Benelli \& Costa-Rosa, 2006), assim como também se mostrou eficaz para cartografar as instituições de Assistência Social a crianças e adolescentes considerados em "situação pessoal e social de risco".

No início do século XXI, atravessam-se grandes transformações socioculturais, produzidas pelo impacto do desenvolvimento tecnológico e da informática no cotidiano. Novas formas de relacionamento, produção, consumo e de produção de subjetividade são geradas e se manifestam. A subjetividade (modos de ser, sentir, pensar e agir constitutivos do sujeito em determinado momento histórico) é tecida, no contexto institucional, pela rede de micropoderes que sustenta o fazer cotidiano (institucional), operando efeitos de reconhecimento/ desconhecimento dessa ação concreta (Benelli, 2004; Benelli \& Costa-Rosa, 2002).

A produção de subjetividade remete fundamentalmente ao plano micropolítico, microfísico das relações instituintes e instituídas no contexto das instituições assistenciais. A Análise Institucional considera que a pregnância e visibilidade das relações pedagógicas, terapêuticas e educativas entre educadores sociais e a clientela, configuradas como relações estáticas entre polos constituídos, não podem cegar para a dimensão em que elas também se apresentam em permanente constituição e ordenação - plenas de vicissitudes, em constante transformação dos lugares e posições no interior das relações, numa pulverização dos espaços e processos instituídos e instituindo outros. As instituições implementadas em organizações e estabelecimentos não apenas realizam - quando realizam - os objetivos oficiais para os quais foram criadas, mas produzem determinada subjetividade em seus vários atores; sujeitos são fundados no interior das práticas, e ao mesmo tempo constituídos no e constituintes do cotidiano institucional (Benelli, 2004). 
O pensamento costuma reificar objetos e sujeitos que só existem enquanto se produzem e são produzidos dentro de determinadas práticas institucionais. As técnicas de vigilância, punição, controle social e produção de sujeitos também estão se sofisticando a partir do suporte da tecnologia de ponta. Mesmo neste contexto de mudanças, as antigas instituições totalitárias ainda não desapareceram da sociedade contemporânea (Benelli, 2004). Goffman (1987, p.11) define a instituição total "como um local de residência e de trabalho, onde um grande número de indivíduos com situação semelhante, separados da sociedade mais ampla por um período considerável de tempo, levam uma vida fechada e formalmente administrada". Seu traço principal é que ela concentra todos os diferentes aspectos da vida de uma pessoa (trabalho, lazer, descanso, tratamento) no mesmo local e sob a autoridade de uma equipe dirigente.

Dentre as práticas sociais de modelagem da subjetividade, a internação em instituições totais tem sido historicamente uma estratégia extremamente frequente. Essas instituições foram e continuam sendo utilizadas como agências produtoras de subjetividade, modelando-a de acordo com o contexto institucional, ao promoverem relações peculiares entre dirigentes e internados, no conjunto das práticas institucionais (Benelli, 2004, 2006a, 2007; Foucault, 1999; Goffman, 1987). Além da presença das instituições totalitárias e disciplinares clássicas, há o florescimento de inúmeras instituições mais abertas, nas quais os indivíduos permanecem boa parte do dia, mas que já não funcionam em regime de internato. Muitos dos estabelecimentos assistenciais parecem enquadrar-se na categoria de instituições que funcionam apenas durante o dia, recebendo eventualmente uma turma de usuários pela manhã e outra no período vespertino, alternando com a escola a tarefa de se ocupar com as crianças e adolescentes tidos como "pessoas em situação pessoal e social de risco". As instituições assistenciais se tornaram mais abertas e flexíveis, abandonando a estratégia do confinamento permanente.

Foucault (1999, p.246) desenvolve a noção de "arquipélago carcerário", expressando com essa ideia a difusão do poder disciplinar pelo tecido social. Essa parece ser uma hipótese interessante para estudar a emer-

544 gência de estabelecimentos abertos e flexíveis para a gestão social de crianças e adolescentes considerados em "situação pessoal e social de risco". Foucault (1999, p.246) afirma que diversas outras instituições, bem além do direito penal, construíram o "arquipélago carcerário": colônias agrícolas para adultos e crianças pobres, abandonadas e vadias; refúgios para tirar moças e meninas da prostituição; colônias penitenciárias industriais; orfanatos para crianças abandonadas ou indigentes; estabelecimentos para aprendizes; fábricas-conventos etc. Houve um alargamento dos círculos carcerários e nessas instituições a prisão foi se diluindo lentamente, até desaparecer por completo. Surgiu também uma série de dispositivos que não reproduzem a prisão "compacta", mas utilizam alguns dos mecanismos e técnicas carcerárias, tais como os patronatos, as obras de moralização, as centrais de distribuição de auxílios e vigilância, a construção de cidades operárias. Haveria uma grande organização carcerária que reúne todos os dispositivos disciplinares que funcionam disseminados na sociedade. As fronteiras entre o encarceramento, os castigos judiciários e as instituições de disciplina tendem a desaparecer, para constituir um grande continuum carcerário que difunde as técnicas penitenciárias até as disciplinas mais inocentes. Ele transmite as normas disciplinares até a essência do sistema penal, e faz pesar sobre a menor ilegalidade, sobre a mínima irregularidade, desvio ou anomalia, a ameaça da delinquência. "Uma rede carcerária sutil, graduada, com instituições compactas, mas também com procedimentos parcelados e difusos, encarregou-se do que cabia ao encarceramento arbitrário" (Foucault, 1999, p.246). Assim como a justiça penal através da prisão transforma o processo punitivo em técnica penitenciária, o arquipélago carcerário transporta essa técnica da instituição penal para o corpo social inteiro, num investimento capilar e microfísico, produzindo sujeitos dóceis, adestrados e úteis. As múltiplas relações de poder atravessam a produção do conhecimento, constituindo campos de saber (Foucault, 1999). Os saberes"científicos"- e dentre eles as ciências humanas - podem ser compreendidos como dispositivos políticos articulados com as estruturas sociais, produzindo efeitos de verdade, poder e saber, que desenham as figuras do delinquente, do louco, da "criança em situação de risco" e do "adolescente infrator", dentre outras.

Ainda de acordo com Foucault (1999, p.250) "...em sua função, esse poder de punir não é essencialmente 
diferente do de curar ou educar", o que faz pensar que vigilância e punição, tratamento (médico, psicológico) e terapia, pedagogia e educação estão unidos, pois sua origem seria a mesma: o poder disciplinar e os saberes das ciências humanas, produzindo realidade social. 0 pedagógico, o terapêutico e a punição seriam irmãos siameses. É nesse sentido também que Foucault (1999, p.251) afirma que "estamos na sociedade do professor-juiz, do médico-juiz, do educador-juiz, do "assistente social"-juiz; todos fazem reinar a universalidade do normativo; e cada um no ponto em que se encontra, aí submete o corpo, os gestos, os comportamentos, as condutas, as aptidões, os desempenhos." Os "dispositivos de normalização" (Foucault, 1999, p.253) avançam pelo tecido social, eles se expandem, se metamorfoseiam e estendem seus efeitos de poder"colocando novas objetividades", enquanto inventam e reinventam subjetividades homogeneizadas.

\section{Paradigmas no campo do Assistência Social}

No campo da Assistência Social, é possível mapear dois paradigmas contraditórios: um pode ser denominado modelo da "incorporação modernizante", e o outro, modelo de "transformação social", de acordo com Tassara (2004, p.103).

O primeiro busca promover uma inclusão excludente; visa a um processo de adaptação sociocultural a partir de um parâmetro cristalizado de padrão social e civilizatório, isento de surpresas que não sejam consequência do próprio aperfeiçoamento científico e tecnológico; seus limites seriam os do modelo capitalista hegemônico. Nesse paradigma, de acordo com Benelli e Costa-Rosa (2010), a "rede social" se reduz a um instrumento de captura dos pobres e desviantes sociais, uma mera estratégia pragmática e operacional para intensificar de modo capilar o cerco aos "indivíduos em situação pessoal e social de risco", fazendo-os circular pelas várias agências sociais de assistência, saúde e educação - Centro de Referência da Assistência Social (CRAS), Centro de Referência Especializado da Assistência Social (CREAS), entidade socioeducativa, unidade básica de saúde, Conselho Tutelar (CT), escola etc.

O segundo visar à abertura ao devir, a uma prática social e política que promove de forma crescente as diferenças e os diferentes, objetivando a emancipação popular. Nesse caso a "rede social" supõe uma prática democrática radical, baseada na autogestão e na autoanálise, e não uma mera instrumentalização técnica e burocrática de instituições, entidades, programas e serviços, fechada num circuito local que seria "a comunidade local", a "cidade" ou o "território municipal". A lógica da "rede" não se limita a uma questão técnica, burocrática, pragmática e operacional, assepsiada de qualquer traço de força política transformadora. Ela se funda em uma concepção de cidadania integral e na defesa da implementação radical de direitos civis, políticos e sociais para todos (Benelli \& Costa-Rosa, 2010). A lógica da"rede" opõe-se à fragmentação e à focalização na administração do "problema social", versão contemporânea do "campo das ilegalidades" descrito por Foucault (1999, p.226), recortado atualmente nas figuras da criança e do adolescente delinquentes, da drogadição, do risco pessoal e social e da criminalidade (França, Rocha, Cruz, Justo \& Cardoso Jr., 2004; Pagni, 2010). 0 "campo das ilegalidades" pode ser administrado e gerenciado por meio da fragmentação e da focalização, recortando figuras sociais enquanto objetos de saber e de intervenção técnica por meio da Assistência Social, da Psicologia e da Pedagogia. Inclusive esses atores sociais considerados "problemáticos" podem ser objeto de exploração de mais-valia pelo sistema econômico, pois o chamado "terceiro setor" movimenta volumosos recursos financeiros na atualidade (Benelli \& Costa-Rosa, 2010).

A "rede" se conecta a tudo e a todos numa teia em permanente ampliação e extensão, em fluxos abertos e em vetores multidirecionais para todos os lados, em todos os sentidos, em múltiplos planos, em abertura incomensurável e imprevisível. Ela jamais se limita a qualquer plano intracomunitário, intramunicipal ou intraterritorial, mas interliga tudo a todos, num processo dialético elevado à máxima potência produtiva e disruptiva. A "rede" costura o impossível e o indizível, o improvável e o invisível; em sua abertura instituinte para o devir inovador e criador, é estrada para o imponderável do desejo (Benelli \& Costa-Rosa, 2010).

A análise das contradições indica o estado dos conflitos que se atualizam e se metabolizam na Assistência Social enquanto instituição, em relação à Demanda Social de que ela é o efeito. Para analisar o estado do jogo de forças institucionais, é preciso especificar as 
principais contradições ativas no contexto, distinguir entre contradição principal e contradições secundárias e compreender os antagonismos decorrentes das diferenças essenciais. Analisando-se a proporção de forças que possui cada um dos polos dos interesses presentes em determinada conjuntura particular, tem-se o índice do estado das contradições. A partir das investigações deste estudo, pode-se supor que, nas entidades assistenciais que atendem a crianças e a adolescentes, situadas no contexto sócio-histórico capitalista e no campo da Assistência Social, predomina um paradigma que se pode denominar "filantrópico", atraindo com sua força gravitacional os saberes, as práticas e os discursos nesse campo institucional. Seu oposto dialético seria um paradigma"socioassistencial", configurando-se mais como uma possibilidade lógica e estratégica no campo, do que como efetivamente constituído.

\section{A razão socioeducativa na Assistência Social à criança e ao adolescente}

Há uma história relativa à infância e à adolescência como alvos das políticas públicas (Cruz et al., 2005). Houve uma construção social dessas categorias (Ariès, 1985; Banditer, 1985; Foucault, 1999; Donzelot, 2001), e à sua invenção sempre estiveram ligadas diversas formas de intervenção, de regulação e de controle social (Buges, 2000; Pagni, 2010). Com efeito, as políticas públicas têm participado da construção de determinadas formas históricas de ser criança ou adolescente, ao utilizarem padrões de normalidade e anormalidade e ao prescreverem etapas evolutivas e cuidados, elaborados pelas ciências humanas, principalmente pela psicologia (Cruz\& Guareschi, 2004; 2009).

No Brasil do século XIX, a institucionalização da infância abandonada começou com a internação em estabelecimentos religiosos, numa parceria com o poder público municipal (Freitas, 1997; Marcílio, 1999; Rizzini, 1997). No início do século XX, com as mudanças sociais e políticas, o Estado começou a ter maior participação nos cuidados com a infância: apareceu o termo "menor", remetendo a uma noção de menoridade ligada sobretudo a questões de criminalidade. Com o crescimento urbano desordenado, os "menores" se tornaram um problema para o poder público (Bulcão, 2002). A estratégia consistia em internar crianças e adolescentes em estabelecimentos correcionais, cujo processo educativo se baseava na disciplina do trabalho (Martins \& Brito, 2001). Eles passaram a ser percebidos a partir da noção de periculosidade, despertando a preocupação com sua gestão e tutela, e deram origem às instituições de internação, que visavam ligá-los a aparelhos de correção, em busca de seu enquadramento, controle e normalização.

Foucault (1999) descreve a sociedade disciplinar e os estabelecimentos que ela implementa, centrados na vigilância e na normalização dos indivíduos. É nesse contexto que também surge a noção de prevenção da delinquência, buscando vigiar aquilo que pode ser potencialmente perigoso. A medicina, a pedagogia, o direito, a psicologia e a psiquiatria passaram a se ocupar com a higienização e controle dos espaços públicos (Cruz et al., 2005). É possível observar a articulação histórica de saberes e poderes, em práticas discursivas e não discursivas, implementando dispositivos produtores da subjetividade infantil e adolescente, tidos como naturais e universais, que passaram a ser objeto psico-médico-biológico-legal, passíveis de ordenação e classificação.

Ao longo do século XX, as políticas públicas buscaram criar medidas sistemáticas de intervenção, visando à recuperação e à reintegração de "menores delinquentes" à vida social, sobretudo por meio dos reformatórios em regime fechado (Martins \& Brito, 2001). Durante a ditadura militar, foi criada a Fundação Nacional para o Bem-Estar do Menor (FUNABEM), pautada em métodos terapêuticos e pedagógicos visando à recuperação e ressocialização dos menores infratores, mas sem sucesso, tendo sido muito criticada.

O ano de 1989 foi declarado o Ano Internacional da Criança, e a infância e a juventude foram temas internacionais importantes durante a década de 1980, culminado com a Convenção sobre os Direitos da Criança de 1989, que incorporou a Doutrina da Proteção Integral, segundo a qual crianças e jovens são considerados pessoas em desenvolvimento e indivíduos vulneráveis. No Brasil, todo esse movimento culminou na publicação do Estatuto da Criança e do adolescente (ECA) (Brasil, 1990). Esse novo dispositivo estabeleceu o caminho para a intervenção popular nas políticas de assistência, traçando as diretrizes da política de atendimento: criação de conselhos municipais, estaduais e nacionais dos di- 
reitos da criança e do adolescente, órgãos deliberativos e controladores das ações em todos os níveis, assegurando-se a participação popular paritária por meio de organizações representativas, segundo leis federais, estaduais e municipais. Iniciou-se então uma fase de desinstitucionalização, caracterizada pela implantação de uma nova política, que amplia quantitativa e qualitativamente a participação da sociedade na elaboração, deliberação, gestão e controle das políticas para a infância, o que é fundamental para a garantia da implementação da Lei (Brasil, 1990).

Apesar dos inegáveis avanços, uma leitura inicial do ECA (Brasil, 1990) permite observar inicialmente alguns aspectos desse documento que merecem ser problematizados: a adoção de uma visão psicológica evolutiva naturalizada e idealizada quanto ao desenvolvimento dos indivíduos, a crença na estratégia da privação de liberdade como medida legal diante das infrações da lei, além das noções complexas de "sociedade", "comunidade"e"família nuclear"no atual contexto social, dentre outras.

A própria noção de crianças e adolescentes em "situação de risco pessoal e social" parece ambígua, pois ela parece vir recobrir as figuras do "menor carente" e do "adolescente delinquente e marginal" na evolução da legislação relativa à infância no país. Crianças e adolescentes se encontram em situação de vulnerabilidade pessoal (podem ficar privadas de condições de vida familiar normal e estável, por exemplo) e social (exposição à mendicância, à exploração sexual, ao mundo do tráfico de drogas, à violência, por exemplo) devido à situação de pobreza na qual sobrevivem; e isso não pode ser isolado dos efeitos estruturais sócio-históricos do modo de produção do capitalismo monopolista contemporâneo. Mas a sociedade também se sente ameaçada e em risco diante da criança pobre de hoje, que pode vir a se tornar o criminoso de amanhã. Daí a importância das entidades assistenciais que possam atender essa clientela. O ECA (Brasil, 1990) ainda contempla a criação dos Conselhos Municipais Tutelares e dos Direitos da Criança e do Adolescente, incluídas no campo de análise dessa investigação.

Situar o cuidado e a atenção à infância e à adolescência no contexto mais amplo da história política do Brasil permite mapear as diversas políticas públicas implementadas nesse campo: alguns períodos da história nacional fornecem pontos de referência que possibilitam estudar as mudanças nas concepções e práticas sociais relativas a esse tema. De um modo muito geral, Merisse (1996, p.43) afirma que o atendimento à infância brasileira pode ser estudado por meio de uma série de fases: uma fase filantrópica inicial, seguida por outra de caráter marcadamente higiênico-sanitária, uma terceira fase de orientação assistencial, e uma quarta fase centrada na dimensão educacional, que perduraria até a atualidade. De modo semelhante, Pinheiro (2004, p.345) apresenta quatro grandes etapas relativas às representações sociais predominantes das crianças e adolescentes na história brasileira: no período do Brasil-Colônia eles foram tomados como objetos de proteção social, a partir do início do Brasil-República tornaram-se objetos de controle e disciplinamento, em meados do século XX passaram a ser objetos de repressão social e, finalmente, a partir das décadas de 70 e 80 do século XX começaram a ser considerados sujeitos de direito. No contexto sócio-histórico, práticas sociais, valores, ações políticas e instituições concretizam e implementam essas diferentes concepções, com constantes embates simbólicos entre as configurações da infância e da adolescência, em momentos de enfrentamento, de superposição e de hegemonia.

Na atualidade, a razão socioeducativa tenta superar a razão criminalizante com relação à criança e ao adolescente pobres. O Código de Menores de 1979 (Brasil, 1984) funcionava a partir de uma lógica que incriminava crianças e adolescentes pobres, considerando-os como "menores em situação irregular e perigosos" para a sociedade. A partir do ECA (Brasil, 1990), crianças e adolescentes passaram a ser considerados sujeitos de direitos, na busca para ultrapassar sua consideração como meros objetos de medidas judiciais. Do combate aos "menores infratores"e seu aprisionamento arbitrário, baseado no modelo da sanção, passou-se a buscar sua proteção integral por meio da promoção de atividades que visem seu desenvolvimento físico, intelectual, emocional, moral, psicológico e social, sob a responsabilidade da sociedade civil e do Estado. A ênfase se deslocou, no discurso e nas práticas, da sanção para a prevenção, educação e promoção social, realizadas por entidades assistenciais. Houve também uma importante alteração terminológica: o termo "menor" foi substituído por "criança e adolescente"; o "delinquente" passou a ser denominado "sujeito em conflito com a lei"; o "delito" 
tornou-se "ato infracional"; e a"pena" ou"punição"foram traduzidos por "medida socioeducativa".

Visando garantir os direitos das crianças e dos adolescentes, o ECA (Brasil, 1990) estabelece medidas de proteção e medidas socioeducativas. As primeiras teriam por objetivo prevenir desrespeito aos direitos, por meio de ações que vão desde a orientação e o acompanhamento às crianças, adolescentes e pais, com programas comunitários de apoio à família, até o abrigo em entidades ou a colocação em família substituta. Já as medidas socioeducativas são aplicadas pelo juizado da Vara da Infância e Juventude quando se verifica a prática de ato infracional pelo adolescente. Elas variam desde a simples advertência, passando por obrigação de reparar o dano, prestação de serviços à comunidade, liberdade assistida, até a internação em estabelecimento educacional, em regime de privação de liberdade, conforme as circunstâncias e a gravidade do ato infracional. A evolução das medidas socioeducativas dependerá da resposta do sujeito à intervenção da Justiça (bom comportamento, matrícula e frequência à escola, apoio da família e outras redes sociais etc.); dependerá também da diligência do técnico responsável pelo acompanhamento da medida e do próprio juiz da infância e da adolescência, que tem o poder de suspender ou conceder progressão de medida. Uma importante investigação das medidas socioeducativas foi realizada por Saliba (2006) que, numa análise vertical, procurou demonstrar como tais medidas, de fato, dissimulam uma prática historicamente consolidada de vigilância e controle do comportamento sobre aqueles que possam representar qualquer tipo de ameaça social.

Na literatura que tematiza os estabelecimentos de proteção de crianças e adolescentes, tanto com relação aos fechados quanto aos abertos, há estudos que apontam para os efeitos positivos da institucionalização de crianças e de adolescentes (Borgheti, 2007; Costa \& Assis, 2006; Morais, Leitão, Koller \& Campos, 2004; Pinheiro, 2004; Santana, Doninelli, Frosi \& Koller, 2004; Siqueira \& Dell'Aglio, 2006), focalizando a dimensão do cuidado, da proteção integral e da socialização, algumas vezes sem maiores implicações problematizadoras. Outros trabalhos, porém, tendem a enfatizar mais seus efeitos iatrogênicos (Benelli, 2002, 2003a, 2003b, 2004; Guirado, 1986; Lemos, 2008; Marcílio, 1998, 2000; Pagni,
2010; Scherer, 2009), mais atentos para a dimensão do controle e da normalização social, respaldados por uma perspectiva analítica crítica.

A especificidade desta pesquisa está no enfoque da análise institucional na investigação de entidades assistenciais voltadas para crianças e adolescentes, em um município do interior do estado de São Paulo. Visa estudar as entidades assistenciais que oferecem programas, projetos e serviços socioeducativos para crianças e adolescentes considerados em "situação social e pessoal de risco". Elas se enquadram no plano das medidas de proteção, mas se autodenominam "entidades assistenciais socioeducativas". Conhecendo-as concretamente e estudando seus programas institucionais, pode-se verificar como elas se arrogam poderes extrajurídicos para implementar projetos e serviços que visam educar, curar e punir, por meio da vigilância e do controle.

\section{Os programas de atendimento a crianças e adolescentes das entidades assistenciais privadas e públicas}

As entidades assistenciais inscritas no Conselho Municipal dos Direitos da Criança e do Adolescente possuem uma pasta individual na qual constam diversos documentos que são exigidos pelo Conselho para conceder o certificado de inscrição: Estatuto Social de acordo com o Código Civil, o ECA (Brasil, 1990) e a Lei Orgânica da Assistência Social (LOAS) (Brasil, 1993), relação nominal da diretoria, ata de eleição e posse, Cadastro Nacional de Pessoa Jurídica (CNPJ), plano de trabalho, relatório das atividades desenvolvidas no ano anterior, balanço patrimonial e financeiro do ano anterior, certificação de recolhimento do Fundo de Garantia porTempo de Serviço (FGTS), certidão de regulamentação de recolhimento do Instituto Nacional de Seguro Social (INSS). Tendo tomado como material de consulta tais documentos, apresentou-se um esboço no qual se procurou desenvolver uma caracterização geral dessas entidades, além de dados relativos aos significantes predominantes que podem ser encontrados em seus "planos de trabalho". A partir desse material e com base num amplo conhecimento do campo de análise, analisaram-se quais seriam os pressupostos teórico-técnicos subjacentes aos "planos de trabalhos", programas, 
projetos e serviços oferecidos pelas entidades assistenciais. De acordo com o levantamento realizado nos arquivos, encontrou-se documentação relativa a um total de 25 entidades inscritas, sendo que algumas delas, tanto públicas quanto privadas, desenvolvem mais de um programa de atendimento a crianças e adolescentes considerados em "situação pessoal e social de risco".

As entidades assistenciais mais antigas do município, tais como orfanatos masculinos e femininos, educandários e creches, foram criadas ainda na primeira metade do século XX, a partir da sensibilidade filantrópica e assistencialista de então, caracterizada pelo humanismo e benemerência de indivíduos ricos e bem intencionados em prover auxílio para a "infância desvalida", sempre com uma preocupação "preventiva" com relação à delinquência e à marginalidade. A função de tais entidades consistia em amparar, acolher, alimentar e educar as crianças e adolescentes pobres, englobando indistintamente as áreas de saúde, educação e assistência social. Isso persistiu da década de 40 até a década de 90 do século XX, quando chegou ao ápice todo um processo de mudanças com relação ao cuidado com a infância e adolescência pobres: o Estatuto da Criança e do Adolescente foi promulgado em 13 de julho de 1990 com a lei federal de número 88.069 (Brasil, 1990). A transformação jurídica afetou as entidades assistenciais focalizadas no público infanto-juvenil carente, e outra lógica teria que ser adotada por elas. Novos equipamentos institucionais foram implementados, tais como o Conselho Municipal dos Direitos da Criança e do Adolescente e o Conselho Tutelar, criados no município respectivamente em 10/8/1992 e em 14/12/1993. Foi nesse sentido, por exemplo, que se criaram entidades preocupadas com os numerosos "meninos de rua" que perambulavam pela cidade, dormindo ao relento, longe de suas famílias, fora da escola, às vezes esmolando, engraxando sapatos e também roubando, buscando sobreviver. Foi inspirado nesses modelos e impulsionado pelo CMDCA que o poder público municipal passou a criar, manter e expandir programas, projetos e serviços para atender crianças e adolescentes, a partir de 1997, por meio da Secretaria Municipal de Assistência Social.

A promulgação da LOAS em 1993, dispondo sobre a organização da Assistência Social no país, também veio produzir impacto nas entidades e no seu modo de funcionamento, pois elas deveriam se ajustar às exigências legais e se atualizar para poderem continuar realizando suas atividades. Orfanatos se transformaram em abrigos, de preferência provisórios, pois o ECA promove a defesa da convivência familiar e comunitária.

O exercício ativo da função de conselheiro municipal permitiu o conhecimento de diversos aspectos dos estabelecimentos assistenciais. Do ponto de vista físico, essas entidades têm muitos aspectos semelhantes: as mais antigas apresentam grande área construída, com pavilhões típicos da metade do século XX, com sala e ambiente espaçosos e enormes áreas abertas, dispondo de campo de futebol, quadra esportiva e espaço arborizado. É típico das entidades disporem de salas para atividades diversas, área de lazer, quadra esportiva ou campo de futebol, piscina, cozinha e refeitório, salas ocupadas pela administração, veículos e equipamentos de informática e audiovisuais. As condições físicas e ambientais não variam muito e tendem a ser usualmente deterioradas pelo tempo e pelo uso, predominando uma estética da pobreza.

As entidades privadas precisam de uma diretoria composta por pessoas idôneas para figurar no organograma institucional (presidente, vice-presidente, secretários, tesoureiro, conselho fiscal etc.) e nos estatutos legais. É possível afirmar que a diretoria poucas vezes exerce suas funções de fato; é comum que ela seja "fantasma" e apenas nominal, com pouca atuação e reduzida efetividade, não se exigindo que seus componentes tenham ingerência no funcionamento da entidade. Isso parece dever-se também ao baixo nível de compromisso social e à ausência de solidariedade que predomina na sociedade brasileira contemporânea, aliados à pouca qualificação e à pouca consciência crítica e política do cidadão. É difícil encontrar quem se disponha a ajudar, e é preciso contar com aqueles que se apresentam ou são convidados, sendo informados de antemão do favor que prestam para a entidade e do prestígio do cargo que se lhes oferece, advertindo-os de que não Ihes será exigido maior compromisso. É que a lei exige as formalidades burocráticas e elas devem ser cumpridas.

Quanto aos funcionários, são necessários alguns educadores (podem ser professores de educação física, 
de música, pedagogos, "arte-educadores" etc.), cozinheiras, secretário, um coordenador ou diretor executivo, trabalhadores de serviços gerais etc. Os voluntários são uma necessidade constante para auxiliar no que for possível: cozinha, secretaria, educação das crianças, promoção de eventos para angariar fundos etc. Os Assistentes Sociais profissionais são poucos. Psicólogos são bastante raros e muitas vezes são voluntários ou estagiários. Predomina a falta de recursos financeiros para fazer frente ao atendimento da clientela nas entidades assistenciais privadas. Elas costumam estabelecer parcerias com o poder público municipal, de modo a receber ajuda na forma de alimentos disponibilizados pela Cozinha-Piloto, ou de serviços viabilizados pela Secretaria Municipal de Educação através de seus servidores: professores da rede, auxiliares de cozinha, escrita, serviços gerais. É preciso ressaltar que é grande a contribuição da prefeitura municipal às entidades assistenciais. Estas também podem ter convênios com a Secretaria Estadual de Desenvolvimento e Assistência Social (SEADS), com a Secretaria Nacional de Assistência Social (SNAS), com o Ministério do Desenvolvimento Social (MDS) para receber auxílio financeiro, mas os aportes estaduais e federais costumam ser irrisórios, congelados em patamares muito baixos já há praticamente uma década. Participando do Conselho Municipal de Assistência Social (CMAS), observou-se que as entidades, por seu lado, não esboçam a menor reação para se organizar e lutar por mais recursos financeiros junto ao Estado.

Já as entidades públicas municipais podem dispor de mais recursos financeiros e de quadro de funcionários mais variado e abundante, embora seja comum que um mesmo Assistente Social ou Psicólogo trabalhe em diversas unidades durante a semana, dividindo seu tempo entre elas. Isso também pode comprometer o atendimento da clientela. As condições físicas também podem ser mais cuidadas e apresentáveis, pois o poder público sabe captar recursos estaduais e federais para cobrir os gastos com o atendimento de crianças e adolescentes considerados "em situação pessoal e social de risco" e sabe como capitalizar politicamente tais investimentos. Na verdade, talvez o poder público tenha se voltado para o atendimento dessa clientela na medida da institucionalização das políticas públicas e da canalização de verbas para esse setor, que ao mesmo tempo

550 revelou-se fértil em termos de dividendos políticos.

\section{"Planos de trabalho" das entidades assistenciais arquivados no CMDCA}

Foi realizada uma leitura global dos "planos de trabalho" e dos "relatórios de atividades" desenvolvidos pelas 25 entidades assistenciais que constam nos arquivos do CMDCA, procurando-se detectar os significantes que organizam a área da criança e do adolescente no campo das práticas institucionais que estão sendo desenvolvidas em uma cidade do interior do estado de São Paulo. Dada a heterogeneidade dos documentos disponíveis, optou-se por selecionar os significantes (termos, palavras, expressões, frases) a partir de uma leitura norteada pelos operadores teóricos adotados, sendo que a classificação numérica foi utilizada apenas como um modo de ordenar, organizar e uniformizar um conjunto de dados ricos, numerosos, complexos e eloquentes. Serão apresentados os significantes mais recorrentes no material analisado, colocando-se os termos entre aspas e seguidos da quantidade de vezes que aparecem, entre parênteses. Quando aparecem apenas uma vez não haverá indicação entre parênteses.

Os textos indicam que os estabelecimentos assistenciais pretendem oferecer "acolhida" (5), fomentar o"resgate da dignidade humana"(5), "amparar e educar" (5) a "crianças e adolescentes em risco pessoal e social" (24), "carentes" (9), "abandonados" (2), em situação de "vulnerabilidade social e de exclusão social" (2), denominando-os também de "assistidos"e"bolsistas"(3). Buscam o "desenvolvimento bio-psico-social-educacional" (20) dos usuários, que também são considerados como sendo "sujeitos em formação" e "pessoas em desenvolvimento". Eles ainda buscam a "defesa e promoção dos direitos da criança e do adolescente" (5), querem proporcionar "proteção, desenvolvimento e socialização de crianças e adolescentes"(5), e para tanto "ofertam auxílio material, orientação educacional, profissional, artística e ambiental" (2). O objetivo de uma das entidades pode ser considerado representativo do campo: "formar e aperfeiçoar crianças e adolescentes para o exercício da cidadania preparando para a vida em sociedade, estimulando a aquisição de hábitos sadios, desempenho de papéis, relações interpessoais, vínculos, sentimentos de cooperação e participação, reintegrando-os na escola, família e comunidade, visando dessa maneira o abandono definitivo das ruas". 
Os objetivos dos estabelecimentos visam a "tirar da rua" (5), "promover ações preventivas para que crianças e adolescentes não se envolvam com a marginalidade" (2), prevenir ${ }^{4}$ e evitar a "mendicância" (4) e "pequenos furtos" (2). Querem "prevenir a exposição de crianças e adolescentes à violência e ao crime" (4), pretendem ainda "prevenir a fuga na drogadição e no tráfico" (3). Afirmam que o ambiente social da sua clientela é caracterizado por"alcoolismo, desemprego, evasão escolar, desqualificação profissional, carências materiais e emocionais". A "pobreza" seria geradora dos "conflitos familiares" que promovem o abandono do lar por parte de crianças e adolescentes. Portanto, seria preciso realizar a"prevenção da ociosidade e riscos dela decorrentes". A "criminalidade, desemprego, subemprego, analfabetismo, baixa renda e ausência de renda" também caracterizam o ambiente social das crianças e adolescentes atendidos, que pertenceriam à "classe social menos privilegiada" (5), à "população de baixa renda" (9). Essa situação exige"uma atuação efetiva em relação à criança e ao adolescente que está sobrevivendo nas ruas e deve buscar alternativas socioeducativas, iniciação ocupacional, mudança de mentalidade e geração de renda para o enfrentamento do atual quadro".

As famílias dos usuários são consideradas"desestruturadas"(5) e"desajustadas"(4), e as entidades querem promover o "atendimento à família" (8), a "convivência familiar e comunitária" (11), "inserir a família no processo educativo" (4), promovendo sua "participação nas atividades desenvolvidas", buscando "amparar a criança reajustando-Ihe a família". Também se pretende "ampliar a compreensão da família a respeito de sua responsabilidade frente à criança e ao adolescente, enquanto primeira instância social, no processo de organização da comunidade". A promoção do atendimento à família inclui "receber visitas regulares de profissionais para atuação nos problemas familiares que geralmente motivam a criança a sair de casa". Essa intervenção também"envolve a doação de cestas básicas, habilitação para o mercado de trabalho, encaminhamento, orientação e integração no projeto de enfrentamento da pobreza".
A maioria das entidades oferece "alimentação" (21) para seus usuários: café da manhã, almoço, lanche da tarde. Também desenvolvem atividades diversas: "culturais" (14), "esportivas" (20), "lazer" (13), "orientação moral e social" (11), "recreação (8), "formação humana e religiosa/espiritual" (12). Querem promover a"formação do cidadão atuante" (3), o "desenvolvimento da cidadania", a "educação para o exercício da cidadania"(25). A cidadania é apresentada como "consciência e garantia de direitos", como algo aprendido tanto no ritual semanal de "hastear a Bandeira Nacional enquanto se canta o Hino Nacional nas sextas-feiras", quanto por meio do "desenvolvimento das potencialidades e valores morais a serem aplicados no dia a dia junto à comunidade".

Pretendem ainda estimular e desenvolver a"integração à família e à sociedade" (19) e a "inclusão social", a "integração ao mercado de trabalho" (22), a "inserção comunitária" (3). As estratégias de trabalho das entidades com a clientela incluem: "trabalhos manuais"(06), "reforço escolar, apoio, acompanhamento escolar e pedagógico" (16), "educação física" (7), "curso de informática" (6), "capoeira" (2) , "fanfarra de banda" (3), "coral" (7), "teatro" (4), "dança" (7), "inserção no mundo digital" (6), por meio de "noções básicas de informática", "biblioteca e leitura"(6), "aulas de idiomas" (3), "cursos de música" (2), "karatê".

Os estabelecimentos assistenciais afirmam que realizam "proteção especial em regime de abrigo" (4), desenvolvem "práticas e atividades socioeducativas"(24) em"regime ou processo socioeducativo em meio aberto" (10), oferecem "educação informal", "apoio psicossocial e sociofamiliar". É preciso lidar com problemas da clientela: "indisciplina"(2), "conflitos nos relacionamentos"(5), "problemas de comportamento"(2), "prática de ato infracional" (2). Para tanto, oferecem "treinamento para a socialização (atitudes educadas para comer, sentar-se, comportar-se)" (19), buscam "estimular mudanças de hábitos, atitudes e melhoria da qualidade de vida", querem melhorar as "relações interpessoais" e promover "condutas desejáveis", além de oferecerem "noções básicas de higiene pessoal, de boas maneiras e de saúde", inclusive "orientação sexual". Com seu trabalho, as entidades pretendem "melhorar as condições de vida e pro-

\section{urve}

- Há, nos textos dos arquivos, uma perspectiva "preventiva" que parece ambígua, ensejando a pergunta: quem previne o quê? quem se previne do quê? A ameaça onipresente parece ser a da delinquência e da criminalidade que rondaria as crianças e adolescentes pobres, hoje vitimando-os e amanhã tornando-os potencialmente perigosos para a sociedade. 
porcionar um futuro melhor" (15) para crianças e adolescentes por meio de "atendimento integral" (9), de "educação integral", buscando que os usuários tenham "sucesso escolar" (5), auxiliando na superação de "deficits e dificuldades de aprendizagem" (11) e de "dificuldades escolares e psicopedagógicas" (3).

As entidades oferecem diversos tipos de atendimentos aos usuários e suas famílias: psicológico (17), fonoaudiológico (6), médico (14), odontológico (11), pediátrico (1), oftalmológico (1) e assistência social (8). Outros profissionais citados são o educador social e os pedagogos. Muitos desses atendimentos são realizados por"estagiários"e "voluntários"(9), ou então são buscados junto aos serviços públicos de saúde. Aparecem ainda atividades tais como "dinâmica de grupo"(4), "ações preventivas contra doenças, gravidez e acidentes" (2). Querem "envolver a comunidade no projeto" (4) e que a "família utilize os recursos comunitários disponíveis para sua autopromoção". Quanto aos profissionais que compõem as equipes de trabalho nas entidades, são oferecidas "capacitações aos educadores" (6) e realizadas "reuniões pedagógicas" (9) de planejamento, monitoramento e avaliação.

Parte integrante dos programas desenvolvidos inclui "atividades ocupacionais" (3), "iniciação ocupacional", "qualificação profissional", "estágios", "treinamentos" para o trabalho, transmissão de "informações técnicas", "cursos pré-profissionalizantes"(3), "formação profissional básica" (5), "artesanato" (7), "horticultura” (3), "jardinagem" (3). A "capacitação e a profissionalização" (15) e a "preparação para a empregabilidade" (8) e o desenvolvimento do"empreendedorismo"ocupam lugar de destaque em diversas entidades assistenciais que atendem crianças e adolescentes, pois elas pretendem "conscientizar da importância do trabalho e de seus benefícios" e inclusive algumas promovem "visitas a locais de trabalho (empresas)" (3). Querem desenvolver "atividades ocupacionais e cursos de iniciação profissional de acordo com a aptidão e interesse de cada criança e adolescente". O"artesanato", por exemplo, serve para "estimular a criatividade a fim de desenvolver na criança/adolescente o gosto pelos trabalhos manuais, preparando-os para desenvolver atividades com fins lucrativos". Os cursos oferecidos por várias entidades são os seguintes: "assistente administrativo" (6), "eletri-

552 cista” (2), "'mecânico,, "pedreiro,", "torneiro mecânico," "jar- dinagem", "panificação", "cozinheira”, "garçom e garçonete", "manicure", "cabeleireira", "construção civil", "office boy", "auxiliar de limpeza/arrumadeira", "secretariado", "baby sitter", "Zona Azul", "marketing pessoal", "Menor Aprendiz" (3), de acordo com o que estabelece a Lei 10.097/2000. Os estabelecimentos assistenciais buscam "estimular a responsabilidade individual e familiar" (8) com relação a crianças e adolescentes, querem "conscientizar as crianças da necessidade das regras sociais existentes na sociedade e do dever de cumpri-las para o seu bem-estar social, físico e psicológico". Ainda visam "propiciar a identidade, voltada ao respeito aos direitos, deveres e limites".

\section{Pressupostos teórico-técnicos presentes na prática institucional e nos "planos de trabalhos" das entidades assistenciais}

A elaboração das análises apresentadas foi baseada numa compreensão global do campo de análise e da situação das entidades assistenciais socioeducativas, a partir de um intenso trabalho do pensamento. O enfoque teórico institucionalista crítico impregnou o conhecimento delas, obtido por meio da função de conselheiro municipal e também pela leitura global dos seus planos de trabalho. O que lastreou as análises realizadas foi um olhar institucionalista que compreende, além dos dados nomeados como "significantes", uma experiência concreta e reflexiva de imersão prolongada no campo de pesquisa, como elemento que amplia a capacidade e a potência analítica para além dos dados documentais. Assim, a partir dos "planos de trabalho"e "relatórios de atividades" desenvolvidos pelas entidades assistenciais que constam nos arquivos do CMDCA, à luz do conhecimento das entidades, deduziu-se que os diversos saberes científicos pedagógicos, psicológicos, sociológicos e assistenciais ainda não foram suficientemente desenvolvidos nesses estabelecimentos. Eles tendiam a funcionar desprovidos de saberes científicos, e muitas vezes não possuíam técnicos qualificados nas diversas áreas das ciências humanas trabalhando efetivamente nos estabelecimentos, sobretudo devido a sua fragilidade financeira.

A pedagogia que predominou no funcionamento das entidades foi basicamente tradicional (Cotrim, 1993; Gallo, 1999; Guimarães, 1985; Libâneo, 1994) 
e oficiosa; normalmente ela não estava formalizada por escrito, mas era concretizada no cotidiano, baseada no senso comum e centrada na autoridade dos adultos educadores, visando à educação moral dos usuários. É provável que dirigentes, técnicos e educadores não tenham clara consciência do que fazem, de como e por quê fazem o que fazem (Dreyfus \& Rabinow, 1995), e, embora o ignorem, os efeitos éticos de suas práticas tendem a ser nefastos para a emancipação psicossocial dos usuários e seus familiares. É comum que os funcionários em geral não se identifiquem com a clientela; normalmente olham para ela a partir dos preconceitos do senso comum, desprezando e estigmatizando os pobres. Os usuários tampouco se alinham com o perfil de excluídos, não parecem ser conscientes da sua real situação e do lugar social que ocupam. Em outras palavras, não se percebem como membros das classes oprimidas, como marginalizados; ignoram seus direitos e, desse modo, não percebem a necessidade de se organizar e de lutar coletivamente pela transformação social em geral, nem sua em particular.

Tais estabelecimentos podem ser considerados plenamente disciplinares em seu modo de funcionar, utilizando operadores clássicos, tais como a instrumentalização do espaço arquitetônico e da distribuição do tempo. Eles buscam retirar crianças e adolescentes das ruas, do ócio e da possibilidade de ingresso na delinquência e na criminalidade. Querem proteger e educar, mantendo-os ocupados, ativos, em exercício constante, ocupando suas mentes e suas mãos, aprimorando sua capacidade de leitura, de escrita e do cálculo, por meio do reforço escolar e da realização de tarefas escolares. O aprendizado da música, do esporte, da pintura, do artesanato, da arte circense, tudo ganha um significado pedagógico, tudo pode ser instrumento sutil ou declarado de ensino e possibilidade de apren- dizagem. Esse arsenal"socioeducativo"5 é o instrumento de inculcação suave e dissimulada de disciplina. A disciplina é a ordem no corpo, nos gestos, na fala, na aparência, na vontade, na conduta, na consciência responsável, no conhecimento dos "direitos e dos deveres e dos limites". O objetivo não seria propriamente a fruição estética, o prazer artístico, o deleite dos sentidos, a produção criadora do belo, o prazer de criar ou de compor uma obra de arte. A finalidade seria a aprendizagem da disciplina, o adestramento do corpo, a docilidade da vontade. Nesse sentido, uma pedagogia científica sobra, ou ainda não faz muita falta.

Uma psicologia científica também seria pouco necessária onde predomina uma educação total que busca produzir indivíduos trabalhadores e utilizáveis no mercado. É importante recuperar e desenvolver a autoestima $^{6}$ e as potencialidades da personalidade do indivíduo, bem como prevenir o comportamento violento e o ingresso na criminalidade. Buscam-se indícios de patologia, de distúrbio psíquico, de "problemas de comportamento", de desajuste emocional e familiar. Tudo isso será corrigido por meio de orientação socioeducativa, de entrevistas de apoio e persuasão, realizadas por educadores e outros técnicos. A psicoterapia individual e/ou grupal é artigo de luxo que raramente se encontra nesse universo. A incipiente presença da Psicologia, quando se manifesta, apresenta características predominantemente patologizantes do indivíduo, descontextualizando a produção de fenômenos na área da aprendizagem escolar e do comportamento social, e remetendo os problemas à interioridade individual (Benelli, 2009; Bock et al., 2002). Seu objetivo maior seria a promoção do ajustamento social e o desenvolvimento das potencialidades individuais, visando à normalização social dos indivíduos. Trata-se de uma psicologia eminentemente tradicional, alienada e alienante, alinha-

\section{VेV}

5 Em uma comunicação pessoal, uma assistente social explicou que o"socioeducativo"seria a união do "pedagógico"e do"terapêutico", expressando, com essa definição, mais do que imaginava. Ela confirmou com seu insight uma suspeita levantada diante desse termo tão comum nas entidades assistenciais, mas que sempre pareceu bastante enigmático e merecedor de análise e reflexão. Haveria uma certa ambiguidade no termo, que oscila entre componentes jurídicos, educacionais, socializadores, assistenciais e protetivos, como informa Costa (2006, p.69).

- O tema do desenvolvimento e/ou do "resgate" da autoestima merece algum comentário, pois ele é relacionado como um dos objetivos mais recorrentes nas entidades assistenciais que atendem crianças e adolescentes considerados "em situação pessoal e social de risco": aparece 12 vezes nos "planos de trabalho", juntamente com a questão do autoconhecimento e da autoconfiança. Embora o tema da autoestima seja bastante presente na Psicologia, como revela a literatura (Avanci, Assis, Santos \& Oliveira, 2007; Bandeira, Quaglia, Bachetti, Ferreira \& Souza, 2005; Gobitta \& Guzzo, 2002; Ito, Gobitta \& Guzzo, 2007; Marriel, Assis, Avanci \& Oliveira, 2006), entende-se que ele indica um alto grau de psicologização dos complexos problemas sociais nos quais estão mergulhados os usuários dos programas socioassistenciais em geral. Como melhorar a autoestima dos indivíduos trabalhando apenas no campo relacional, comportamental e emocional, sem produzir interferências transformadoras nas condições concretas de vida dessas crianças e adolescentes? 
da com um paradigma médico e medicalizante da vida social em geral.

Nos arquivos, foram encontradas algumas amostras da presença de uma psicologia extremamente tradicional, individualizante e adaptacionista: duas propõem atividades psicopedagógicas corretivas da criança enquanto indivíduo portador de "deficit de atenção ou de habilidades motoras", "defasagens ou dificuldades de aprendizagem", diagnosticadas pelos educadores das entidades, predominantemente entre crianças pobres de $1^{\circ}$ a $5^{\circ}$ ano (1 a a $4^{a}$ série) do Ensino Fundamental, propondo projetos de "acompanhamento dos alunos com dificuldades ou defasagens educacionais". Nisso as entidades não inovam, pois a literatura referente ao tema dos "problemas de aprendizagem" das crianças e aos "problemas de ensinagem" das escolas é abundante (Collares \& Moyses, 1996; Ferreiro \& Teberosky, 1985; Moyses \& Collares, 1992; Oliveira, 1993; Patto, 1984, 1990, 1997; Tuleski \& Eidt, 2007; Vygotsky, 1988; Weisz, 1987).

Vejam-se alguns aspectos de um dos raros projetos da área de psicologia encontrados nos arquivos, elaborado por uma psicóloga que trabalha numa escola particular que oferece bolsas para alunos carentes, intitulado "Indisciplina e conflitos nos relacionamentos dos alunos". Ela pretende "buscar diagnosticar problemas emocionais, de disciplina, de relacionamento e psicológicos" entre os alunos, visando "prevenir situações de risco e alertar pais e responsáveis". Seu objetivo é auxiliar na "formação de cidadãos produtivos, participativos, críticos e responsáveis". Dentre as atividades propostas, a psicóloga pretende utilizar "dinâmicas de interação social para amenizar conflitos nos relacionamentos e impor limites, sempre trabalhando a indisciplina", empregar "técnicas de relaxamento psicológico como estratégia para amenizar agitação e ansiedade", além de lançar mão de "jogos pedagógicos com o objetivo de impor limites, concentração e trabalhar também as funções motoras e cognitivas".

No mesmo estabelecimento, uma fonoaudióloga apresenta um projeto que "visa à prevenção e à reabilitação dos indivíduos que apresentam problemas de linguagem, comunicação oral e escrita, voz e audição", por meio de uma intervenção preventiva "auxiliando nas dificuldades que possam surgir eventualmente no 554 transcorrer do desenvolvimento humano". O fo- noaudiólogo atuaria "dando aos professores sugestões técnicas que ajudem a preparar as crianças para a alfabetização, auxiliá-las no processo de alfabetização propriamente dito assim como em etapas posteriores a ele. Essa função ajudaria a prevenir problemas futuros, ficando evidenciado assim, o caráter profilático desta participação". Esse profissional trabalharia como assessor dos professores e também faria o processo de triagem individual com crianças que eventualmente manifestassem dificuldades ou alterações em habilidades e funções ligadas à comunicação oral ou escrita, de voz e audição. Outra função seria orientar os pais das crianças, sobretudo das que manifestassem "distúrbios de comunicação". Nota-se que a fonoaudióloga não demonstra nenhuma problematização da especificidade da realidade social e educacional tipicamente ofertada pelo Estado para os filhos dos membros das classes populares (Patto, 1984; 1990; 1997) e parece adotar uma perspectiva clínica centrada no indivíduo, de caráter profilático e reabilitador, numa atitude teórico-técnica tipicamente conservadora. Nisso ela se aliaria aos educadores orientados pela pedagogia tradicional e patologizante dos indivíduos, desconsiderando ingenuamente o contexto social da clientela que frequenta a entidade socioeducativa.

Numa outra entidade assistencial, um psicólogo propõe desenvolver um "espaço de psico-dinâmica de grupo", visando oferecer às crianças "apoios alternativos onde possam vivenciar aspectos de sua personalidade, experimentar situações de conflito e questionamento e direcionar suas emoções". Os grupos seriam compostos por crianças de idade semelhante, reunindo entre 15 e 18 indivíduos, sob a orientação do profissional psicólogo. A atividade duraria uma hora e seria realizada uma vez por semana. "As crianças que apresentarem maiores dificuldades psicopedagógicas, passarão por um atendimento individualizado com o psicólogo responsável, alcançando o processo terapêutico". O psicólogo se propõe também promover a "reaproximação e orientação familiar", além de "coordenar grupos operativos com os profissionais envolvidos na entidade". Ele oferece atendimento psicológico e psicopedagógico para as crianças, atendimento às famílias dos usuários e orientação e apoio à equipe técnica. O texto diz ainda que, como a entidade não dispõe de recursos próprios para efetivar sua contratação, é preciso solicitar ajuda para 
mantê-lo no serviço. A avaliação do projeto indica que "o trabalho realizado com as crianças alcançou uma dimensão importantíssima, em nível de autoestima, valorização de opiniões, discussões a respeito de família, drogas, sexualidade, sendo todas elas alicerçadas pela orientação e encaminhamento psicológico."Observa-se que, a partir da forma como está redigido esse projeto, além de superestimar as possibilidades do grupo terapêutico, parece ser o caso de um trabalhador voluntário que está pleiteando se transformar em empregado formal.

Ainda outro projeto relacionado com o ensino de música para crianças e adolescentes tem como objetivo fundamental "proporcionar uma atividade laboral diferente e atrativa que possa no futuro auxiliar na complementação da renda familiar além da preparação para a vida e ocupar seus dias e suas mentes", demonstrando claramente uma instrumentalização socioeducativa do ensino musical, com finalidades exclusivamente disciplinares, ignorando a dimensão da fruição estética e do enriquecimento humano gratuito que a música pode comportar.

Do ponto de vista sociológico, predomina uma perspectiva funcionalista que pretende buscar a adaptação dos indivíduos à vida social. Não há, nos textos, nenhuma crítica ou análise da produção social e histórica dos diversos problemas sociais. Pode-se observar que os dirigentes e educadores sociais que atuam nas entidades não têm consciência do lugar que ocupam nem da tarefa que desempenham na sociedade, ao atender a encomenda de gerenciar a periculosidade dos pobres. Quando a leitura crítica da realidade aparece, não se tiram as devidas consequências para a implementação de um trabalho assistencial que seja realmente transformador, e rapidamente se desliza para as práticas assistencialistas comuns. Aparentemente, a função social de tais estabelecimentos seria de controle social, no sentido mais clássico proposto pela sociologia (Lakatos, 1990), de adaptação social por meio de um assistencialismo ingênuo e emergencial, e da promoção meramente integradora, que pretende fundamentalmente, por todos os meios, atrelar os indivíduos ao aparelho de produção e consumo, atuando preventivamente para que os pobres não se rebelem nem ingressem na criminalidade.
O que se pode notar nesses documentos de arquivo é um deslizamento do discurso, que passa do plano dos direitos de crianças e adolescentes para uma perspectiva social muito tradicional, própria do que se pode denominar como "teoria da marginalidade" (Saviani, 1988). De acordo com essa teoria social, as carências e injustiças sociais existentes na sociedade seriam solucionadas e superadas por meio da participação organizada dos marginalizados, num processo que visaria sua integração no tecido social. O conceito de marginalização indicaria a existência de indivíduos que estão à margem e fora da vida social e são, portanto, "carentes", e a superação dessa condição viria por meio de sua integração ao sistema social vigente. As ideias de "desenvolvimento comunitário", "promoção social", "participação e organização popular" e "integração social", típicas do discurso oficial, remetem claramente a uma perspectiva social conservadora e tradicional, que desconhece e nega a existência da sociedade capitalista, dividida em classes sociais antagônicas e em conflito. No plano sociológico, a "teoria da marginalidade" remete a uma visão funcionalista e idealista da sociedade.

Não é difícil notar que tanto o senso comum quanto os técnicos responsáveis pela formulação de políticas sociais e pela organização de serviços apresentam uma concepção reacionária relativa à família, vendo-a a partir de categorias valorativas tradicionais: as famílias são capazes ou incapazes, doentes ou sadias, normais ou anormais, desestruturadas ou estruturadas. Na concepção funcionalista e sistêmica de família, à mulher é designada a responsabilidade "natural" de cuidar e educar os filhos, característica que permite seu julgamento moral. O pai representaria a figura de autoridade e o provedor do lar. Essa abordagem transclassista ocupa-se apenas com a questão da distribuição territorial das famílias consideradas em "situação de vulnerabilidade". A intervenção junto à família dessas crianças e adolescentes é frisada constantemente, e pode-se dizer que as famílias, portanto, seriam monitoradas, orientadas, auxiliadas, cooptadas e também policiadas por intervenções dos agentes sociais dos programas institucionais.

Na análise da documentação contida nos arquivos, poucas vezes se encontram referências conceituais extraídas da Política Nacional de Assistência Social (Bra- 
sil, 2004) e do Sistema Único de Assistência Social (SUAS) (Brasil, 2005). É possível afirmar que as entidades ainda não incorporaram a novidade da Assistência Social aí consignada, que veio regulamentar a Lei Orgânica da Assistência Social (Brasil, 1993). Também o ECA (Brasil, 1990) ainda ressoa timidamente nos textos produzidos pelas entidades, revelando uma apropriação insuficiente de sua proposta. Provavelmente isso se deve ao fato de que essa nova organização jurídica e institucional da Assistência Social no território brasileiro é bastante recente, propondo um novo paradigma no qual o indivíduo é considerado como cidadão e como sujeito de direitos. Analisando os documentos oficiais produzidos pelo Estado brasileiro quanto a Assistência Social, observa-se que seu discurso propõe objetivos que buscam superar no plano teórico-técnico a filantropia, a ajuda caridosa, o assistencialismo, o favor paternalista de autoridades políticas, de matiz predominantemente patrimonialista, e também a benemerência dos ricos generosos.

Sabe-se que, ao longo da história, essas foram algumas das variadas estratégias utilizadas para aliviar a pressão social e, ao mesmo tempo, manter as camadas mais pobres da sociedade sob tutela e controle, por meio de medidas compensatórias. A nova Assistência Social quer ser emancipatória e construtora de cidadania, caracterizando-se como política pública, descentralizada, participativa e democrática, sendo um direito não contributivo, juntamente com a saúde. A legislação do Sistema Único de Assistência Social (SUAS) (Brasil, 2005) pode ser considerada bastante arrojada, e o discurso da Assistência Social se radicaliza na defesa de direitos para quem está excluído dos benefícios construídos pelo atual estágio civilizatório. Mas isso tudo ainda não parece ter sido assimilado pelas diversas entidades que implementam a Assistência Social em que estão inscritas nos conselhos municipais. Os "planos de trabalho" e os "relatórios de atividades" mostram-se documentos bastante sofríveis, com pouca consistência teórico-técnica, tornando evidente o elevado grau de amadorismo de muitas empreitadas institucionais.

A Assistência Social passa a ser organizada e estruturada por meio do avanço da informática, criando diversos aplicativos visando à gestão, controle, implementação, avaliação, monitoramento e fiscalização do sistema SUAS (Brasil, 2005). Trata-se de sofisticação tecnológica que transita para a sociedade de controle (Deleuze, 1992), superando as dimensões puramente disciplinares da atualidade. É interessante considerar que a revolução operada no plano jurídico e legal tem exigido das entidades, que permanecem grosseiramente assistencialistas e disciplinares, uma grande atualização e adaptação às novas exigências legais, visando garantir sua institucionalidade. Exige alinhamento com o novo modelo de gestão e com o novo discurso, bem como que busquem manter sua viabilidade operacional por meio da captação de recursos financeiros junto aos órgãos públicos municipais, estaduais, federais e também junto a agências privadas nacionais e internacionais.

Ao longo do ano de 2008, exercendo o mandato de conselheiro municipal, participou-se de 23 reuniões de trabalho do Conselho Municipal dos Direitos da Criança e do Adolescente (CMDCA) e de 21 reuniões do Conselho Municipal de Assistência Social (CMAS), bem como de diversas atividades, tais como visitas a entidades, organização e participação em cursos de capacitação e em diversos eventos na área. No ano de 2009, participou-se de 22 reuniões do CMDCA e de 21 reuniões do CMAS. Colaborou-se na organização e realização das Conferências Municipais dos Direitos da Criança e do Adolescente e também na Conferência Municipal de Assistência Social, ambas realizadas no ano de 2009.

Tendo participado de diversos encontros promovidos pelos conselhos municipais nos quais se pretendeu capacitar e orientar os gestores dos estabelecimentos socioeducativos, nota-se que eles não parecem se interessam pelo SUAS (Brasil, 2005), pois buscam prioritariamente financiamento - e esse, por minguado que seja, continua vindo de fontes federais, estaduais ou municipais, sendo gerido pelas autoridades políticas locais. O que parece interessar então para as entidades seria cortejar e solicitar apoio financeiro de forma personalizada junto às figuras políticas locais, começando pelo prefeito, passando pelos deputados, vereadores e pelo secretário municipal de Assistência Social. Observa-se que a lógica que impera na Assistência Social, no âmbito do município, ainda seria completamente presidida pelos interesses políticos das autoridades que ocupam cargos do Executivo. De acordo com a experiência concreta realizada, participando intensamente das atividades dos conselhos municipais, considera-se 
que estes são manipulados e não têm como estar à altura de suas atribuições e prerrogativas legais, ficando reduzidos a uma função subordinada, meramente formal e burocrática, no contexto da política municipal de Assistência Social, emitindo pareceres meramente cartoriais, quando solicitados.

Nesse sentido, o SUAS (Brasil, 2005) aparece como uma ingerência burocrática a mais, desnecessária e inclusive excessiva, diante das urgências cotidianas dos pragmáticos dirigentes das entidades assistenciais. 0 SUAS (Brasil, 2005) viria recobrir a filantropia bem intencionada que é empreendida historicamente pelas entidades. Estas resistem passivamente e tendem a desconhecer ou a ignorar as novas propostas governamentais - que estão em busca de hegemonia no campo da Assistência Social, mas que não parecem trazer auxílio concreto significativo para o trabalho das entidades, senão que representam a implantação de um maior controle sobre elas.

Conhecendo o cotidiano dos estabelecimentos por meio de visitas de observação, verificou-se ser comum que dirigentes das entidades não queiram contratar técnicos que demonstrem capacidade profissional e crítica mais desenvolvidas, pois tendem a se sentir ameaçados por profissionais inteligentes, criativos e perspicazes que podem tomar seu lugar ou vir a descobrir eventuais irregularidades administrativas na condução do estabelecimento. Predomina a mentalidade de"gueto" nas entidades, e normalmente o dirigente elabora pessoalmente projetos para a captação de recursos, sem contar com assessoria técnica especializada de funcionários da área da educação, serviço social e psicologia, quando tais profissionais existem. Às vezes, duas ou três pessoas (diretor, coordenador, secretário, educador etc.) se constituem na principal liderança da entidade e trabalham arduamente por sua manutenção e funcionamento, mantendo também, evidentemente, seus empregos. Esse líder e alguns auxiliares mais diretos de sua confiança, ou mesmo um grupo de liderança, podem revelar um comportamento autocrático, reservando para si as tarefas de pensar e planejar, deixando aos demais a mera execução do trabalho.

Desse modo, o "plano de trabalho" elaborado pelos dirigentes das entidades tende a se reduzir a um projeto pedagógico muito incipiente e a um instrumento burocrático para exibir às autoridades ou para con- seguir financiamento. $\bigcirc$ "plano de trabalho" não é produzido coletivamente e tampouco precisa ser conhecido e aplicado concretamente, não superando muitas vezes uma função de justificativa retórica para a existência e funcionamento da entidade. E geralmente se trata de um funcionamento disciplinar, que dispensa grandes teorizações, exibindo o pragmatismo possibilista que parece reinar soberano no cotidiano institucional das entidades, conforme a experiência de campo demonstrou.

\section{Considerações Finais}

\section{Os efeitos éticos das entidades assistenciais}

Com lastro numa perspectiva teórica institucionalista crítica, que iluminou uma longa imersão problematizadora no campo no qual se inserem as entidades assistenciais denominadas socioeducativas, e após análise de seus "planos de trabalho", é possível se apresentarem algumas conclusões sobre suas atividades. Se há algumas décadas o modelo de gerenciamento das crianças pobres era regido pelo equipamento judiciário que empregava meios e instrumentos claramente repressivos e coercitivos, o atual modelo continua grosseiramente disciplinar, mas também pode utilizar meios de controle mais sofisticados e suaves ao implementar saberes científicos advindos de uma pedagogia conservadora, uma psicologia tradicional, uma sociologia funcionalista e uma assistência social alienada.

As ciências humanas podem oferecer um arsenal teórico-técnico abundante para o cultivo e o cuidado institucional de crianças e adolescentes pobres, num intenso processo de psicologização, pedagogização e sociologização da infância e da adolescência (César, 2008). Essa é a ambiguidade de tais saberes, pois tanto podem ser utilizados para o atendimento da encomenda de controle e tutela sobre os pobres, quanto para tentar articular as demandas dos segmentos socialmente subordinados - embora, no atual estágio de funcionamento dessas instituições, esta última possibilidade só possa ser operada nas brechas de práticas instituídas e utilizando taticamente algumas das autorizações ditadas no discurso - ideológico - recentemente chegado ao campo das políticas públicas de Assistência Social. Isso, 
entretanto, revela-se bastante difícil, tanto pela situação de penúria econômica geral, quanto pela falta de injeção de recursos que possam aumentar a capacidade dos profissionais em relação à análise e crítica acerca da entidade e do próprio contexto social. Com efeito, a sociedade contemporânea exigiu do Estado brasileiro a mudança de discurso e a realocação de recursos, não só para os excluídos de sempre, cuja situação tem ficado cada vez mais grave, mas também para as novas fileiras de excluídos da produção e consumo, que são geradas de modo acelerado, em razão das características tanto gerais quanto locais do Modo de Produção Capitalista em sua fase de globalização e de consumo.

Assiste-se hoje a um fenômeno inédito no campo das políticas públicas, mesmo naquelas de suprimento dos "excluídos": onde antes se viam concessões táticas às reivindicações, vê-se agora mais claramente a hipertrofia do assistencialismo como política espontânea, imitando a política nacional de saúde.

É preciso não esquecer essa diferença: o Sistema Único de Saúde (SUS) é um dispositivo no campo da saúde e da sociedade, conquistado no contexto de lutas sociais importantes, que se destacam na história do país, e cuja existência só é mantida à custa de um árduo processo de luta cotidiana. Não é o caso do Sistema Único de Assistência Social (SUAS), que se configura como efeito de "reivindicações passivas" e como política de mera reposição do mínimo para a sobrevivência física. Embora em seu discurso ideológico deixe escapar alguns clarões de matiz revolucionário, uma análise um pouco exigente de sua configuração de saberes e práticas logo revela seu caráter de política de "suprimentos", espécie de "política de redução de danos", sem a menor possibilidade de interferir na "situação danosa". É necessário muito mais do que ímpetos revolucionários voluntaristas, mesmo que estes envolvam todo o conjunto dos trabalhadores na área de Assistência Social.

Essa análise fria, entretanto, não é argumento para a apatia e muito menos para a conivência com as graves situações cotidianas, que aí veem oferta para a possibilidade de suas demandas. A sintonia com as pulsações instituintes e mesmo revolucionárias, onde quer que elas se apresentem, sempre é ocasião para relançar sua força, ampliando possibilidades manifestas ou demandadas pelos indivíduos; mas isso não é o mesmo que pretender elevar o SUAS à categoria de dispositivo de luta de interesses subordinados ou mesmo excluídos, capaz de impulsionar diretamente a transformação social.

As entidades assistenciais funcionam de modo complementar ao período escolar, acolhendo em regime aberto crianças e adolescentes, para desenvolver atividades pedagógicas, esportivas, assistenciais, psicológicas, profissionalizantes e socializadoras, visando integrar essa clientela ao conjunto da vida social, comunitária e familiar normais. Dessa forma, imagina-se evitar que as crianças e adolescentes fiquem expostos a situações pessoais e sociais de risco, para si e para a sociedade. Certamente não há nada de mal nisso. Mas há uma ausência completa nesse cenário: onde está a dimensão política e transformadora dessas entidades? O que se nota é uma total despolitização do tema da infância e da adolescência consideradas em "situação pessoal e social de risco", por meio de sua mistificação científica, técnica e burocrática.

No universo da Assistência Social, a constelação criança/adolescente orbita em torno do astro-rei "socioeducativo", e todas as atividades desenvolvidas nas entidades assistenciais são recobertas por esse significante-mestre que conota dimensões pedagógicas e terapêuticas, educativas e corretivas, de vigilância e prevenção, de controle e normalização. As entidades assistenciais demonstram em seus projetos pedagógicos, ainda que formalmente denominados "planos de atividades", o que poderia ser chamado de um certo furor corretivo e correcional com relação a crianças, adolescentes e famílias. Deduz-se esse elemento correcional por meio de uma leitura global dos "planos de trabalho" das entidades, atraídos por um conjunto de significantes recorrentes nos textos, bem como pelo conhecimento de seu funcionamento cotidiano. Observa-se que as entidades se propõem a fazer "proteção integral", "proteção básica", "proteção especial de média e alta complexidade", de acordo com o jargão atual da Assistência Social, mas se arvoram em autoridades parajudiciárias e pretendem ditar a pauta de conduta correta e comportamento ajustado, e das atividades conformes e adequadas. Querem transformar as crianças em bons filhos e em alunos exemplares, querem tornar as famílias tidas como "desestruturadas"em famílias devidamente estruturadas, talvez idealmente constituídas por mães amorosas e do lar, por pais responsáveis e provedores, por 
filhos obedientes. Buscam promover uma educação que se pretende "total" (Foucault, 1999), e "integral", prometendo cobrir as dimensões "bio-psico-sociais" dos usuários. Querem "educar", "socializar", "ressocializar", "treinar", "ampliar o repertório de competências e habilidades", "desenvolver", "aprimorar", "estimular, capacitar, incentivar o desenvolvimento", "ensinar", "moldar o caráter", formatar a personalidade, produzir indivíduos como sujeitos sujeitados e dóceis, sobretudo como indivíduos úteis - embora empreguem o discurso da autonomização e do exercício da cidadania.

Há um autêntico furor em "formar para o trabalho", em "promover a iniciação à profissionalização", em "capacitar para o mercado de trabalho", em "inserir no mercado de trabalho", em treinar e profissionalizar. Passando pelo artesanato, por oficinas de pintura, bordado, crochê e costura, pelos cursos de "formação de trabalhadores domésticos", cabeleireira, manicure, auxiliar administrativo, "office boy", eletricista, panificador, técnico em informática, o que se visa é a construção dos usuários como empregados. A "promoção da integração ao mercado de trabalho" está no artigo segundo da LOAS e o "direito à profissionalização" também consta no ECA. Mas será que as crianças e adolescentes apresentam "aptidão e interesse" apenas por essas ocupações? É curioso, pois a universidade, por exemplo, não consta no horizonte das possibilidades que as entidades propõem para sua clientela. O homem contemporâneo é o indivíduo assalariado, aquele que vende sua força de trabalho no mercado, é o trabalhador, o empregado. A intenção parece ser produzir empregados.

Alguma vez se fala em "empreendedorismo" (Souza, 2006), mas não se parece supor que membros das classes populares possam vir a ser patrões, nem se espera que eles possam inventar formas criativas e originais de produzir e ganhar dinheiro. O senso comum pode dizer que os ricos são empreendedores por natureza, enquanto os pobres poderiam ser considerados no máximo astutos, em sua busca de alternativa para sobreviver. O discurso do "empreendedorismo" pretende ensinar a adolescentes e jovens pobres o jargão e algumas técnicas de comunicação do mercado capitalista, ensinar algumas regras básicas do jogo social do mercado competitivo, instilando a crença de que o indivíduo, quando desenvolve suas potencialidades e se torna "empreendedor de si", pois só dispõe de si mesmo para vender no mercado de trabalho, pode alcançar o sucesso por si mesmo. Desse modo, faz com que ele creia que tudo depende dele mesmo, exclusivamente, tanto seu sucesso quanto seu fracasso.

Aparentemente, "formar para a cidadania","promover a cidadania", pelo que se depreende, a partir da documentação compulsada e da realidade observada, poderia ser traduzido em produzir indivíduos trabalhadores, sabedores dos seus direitos formais garantidos pela lei - mas inoperantes e ausentes em seu cotidiano de vida. O que restaria aos "quase profissionais" egressos das entidades assistenciais seria cumprir suas obrigações, resignar-se com suas precárias condições de vida, sem gritar, sem rebelar-se, "porque a vida é assim mesmo", evitando a todo custo a via da criminalidade e da delinquência. Assim se ensina o respeito e a obediência às normas e leis, às regras da vida social, moldando indivíduos conformes, adaptados, resignados ao lugar que Ihes toca na estrutura social.

A perspectiva ética da Análise Institucional, de modo congruente, obriga a encarar resolutamente a atual forma com a qual se apresenta a razão socioeducativa, buscando interpelar os profissionais encarregados da atenção às crianças e aos adolescentes pobres no contexto institucional das entidades assistenciais. A luta pelos direitos de cidadania dessa população, e também em favor de seus desejos e de suas expectativas, deve incluir a transformação das entidades assistenciais, que hoje se limitam quase que somente a gerenciar os "riscos" a que ela está sujeita.

Concluindo, a investigação realizada indica que a função das entidades assistenciais parece bastante centrada numa ortopedia do comportamento, por meio da qual se busca produzir determinados efeitos no caráter, personalidade, conduta e hábitos de crianças e adolescentes. Proteção, prevenção, controle, produção de indivíduos dóceis e úteis, que, apesar da situação de vida absolutamente desfavorável, não ingressarão na criminalidade nem na rebeldia contestadora da (des)ordem institucionalizada: essa a função da Assistência Social como tecnologia social de controle dos pobres e miseráveis, evitando a organização e multiplicação das ilegalidades populares.

Para enfrentar esse duro diagnóstico, seria preciso desenvolver ações no plano teórico-técnico, jurídico, 
político e sociocultural, que estivessem orientadas para a transformação social. Acredita-se que, no plano pedagógico, seria muito útil a leitura e discussão da obra de Paulo Freire e Vygotsky (1988) para pensar a atuação educativa nas entidades assistenciais, de forma alinhada com os interesses dos grupos subordinados. Na dimensão sociológica, o exercício de uma análise dialética e crítica da realidade social contemporânea, assim como uma Psicologia Social crítica, também seriam valiosos para descristalizar as práticas e discursos moralizantes, os preconceitos tradicionais e o senso comum improvisador que predominam nas entidades assistenciais, e poderiam servir de pretexto e alavanca para abrir horizontes para a invenção, para a criação de novas práticas sociais. Nesse sentido, a opção adotada nesta investigação é por uma perspectiva que politize de modo radical e consequente os esforços que visam ao equacionamento do problema social, buscando superar o controle social exercido sobre os pobres, indo na direção de um alinhamento com seus interesses, buscando e exigindo a transformação social. É importante preparar os indivíduos para uma inclusão social que permita sua inserção nos conflitos e contradições sociais pelos quais estão atravessados, para além de meros reprodutores alienados. Ao contrário do que costuma pensar o senso mais comum, a abertura da disposição para habitar os conflitos e as contradições de modo crítico pode ser a melhor maneira de prevenir os efeitos de seu recalcamento, sob as diversas formas da crua transgressão, cuja consequência é sempre pior para os próprios indivíduos.

Como alternativa e proposta de encaminhamentos que visem ao equacionamento das questões, conclui-se o presente trabalho propondo uma intervenção institucional que busque colocar os profissionais educadores bem como as equipes dirigentes dos estabelecimentos socioeducativos - considerados como a principal tecnologia da atenção socioeducativa - na posição de grupo de trabalho eticamente implicado, de acordo com os pressupostos teórico-técnicos adotados.

Se os conhecimentos dos profissionais que atuam nas entidades assistenciais, no atendimento a crianças e a adolescentes, são normalmente implícitos, tácitos e fragmentários, não se trata de substituí-los de modo autoritário e arrogante por saberes científicos psicológicos, pedagógicos ou sociológicos através de cursos de qualificação que parecem produzir apenas mais "incapacidade treinada" (Patto, 1990). Entende-se que o mais adequado seja realizar um trabalho permanente com pequenos grupos de educadores, nas próprias entidades. Para tanto, há alguns princípios básicos que devem nortear tais intervenções: (a) utilizar um enfoque dialético do ambiente socioeducativo, considerando-se as variáveis relativas aos usuários, aos educadores e ao contexto institucional; (b) garantir uma comunicação dialógica e participativa, adotando-se um formato acessível, aceitável e utilizável pelos educadores, tanto para transmitir informações quanto para construir projetos, objetivos, planos de trabalho e a organização democrática da entidade; (c) induzir uma mudança no sistema de crenças e valores dos educadores, com respeito às finalidades da entidade e à socialização e educação oferecidas, com vistas ao empoderamento dos usuários enquanto sujeitos de direitos. Um modo interessante de promover a aplicação de tais princípios é a realização de um processo de análise institucional.

\section{Referências}

Ariès, P. (1985). História social da criança e da família. Rio de Janeiro: Nova Fronteira.

Avanci, J. Q., Assis, S. G., Santos, N. C., \& Oliveira, R. V. C. (2007). Adaptação transcultural de escala de auto-estima para adolescentes. Psicologia: Reflexão e Crítica, 20 (3), 397-405.

Bandeira, M., Quaglia, M. A. C., Bachetti, L. S., Ferreira, T. L., \& Souza, G. G. (2005). Comportamento assertivo e sua relação com ansiedade, locus controle e auto-estima em estudantes universitários. Estudos de Psicologia (Campinas), 22 (2), 111-121. doi: 10.1590/S0103-166X2005000200001.

Banditer, E. (1985). Um amor conquistado: o mito do amor materno. Rio de Janeiro: Nova Fronteira.

Baremblitt, G. F. (1998). Compêndio de análise institucional e outras correntes: teoria e prática. Rio de Janeiro: Record.

Barus-Michel, J. (2004). O sujeito social. Belo Horizonte: PUC-Minas.

Benelli, S. J. (2002). O internato escolar como instituição total: violência e subjetividade. Psicologia em Estudo (Maringá), 7 (2), 19-29.

Benelli, S. J. (2003a). Dispositivos disciplinares produtores de subjetividade na instituição total. Psicologia em Estudo (Maringá), 8 (2), 99-114.

Benelli, S. J. (2003b). O internato escolar "O Ateneu": produção de subjetividade na instituição total. Psicologia USP, 4 (3), 133-170.

Benelli, S. J. (2004). A instituição total como agência de produção de subjetividade na sociedade disciplinar. Estudos 
de Psicologia (Campinas), 21 (3), 237-252. doi: 10.1590/S0 103-166X2004000300008.

Benelli, S. J. (2006a). Pescadores de homens: estudo psicossocial de um seminário católico. São Paulo: Unesp.

Benelli, S. J. (2006b). Paradigmas eclesiais e pedagógicos na formação sacerdotal institucional: uma investigação em Psicologia Social. Revista Eclesiástica Brasileira, 66 (264), 807-841.

Benelli, S. J. (2007). A produção da subjetividade na formação contemporânea do clero católico. Tese de doutorado nãopublicada, Instituto de Psicologia, Universidade de São Paulo.

Benelli, S. J. (2009). A cultura psicológica no mercado de bens de saúde mental contemporâneo. Estudos de Psicologia (Campinas), 26 (4), 515-536. doi: 10.1590/S0103-16 6X2009000400012.

Benelli, S. J., \& Costa-Rosa, A. (2002). A produção da subjetividade no contexto institucional de um seminário católico. Estudos de Psicologia (Campinas), 19 (2), 37-58. doi: 10.15 90/S0103-166X2002000200003

Benelli, S. J., \& Costa-Rosa, A. (2006). Movimentos religiosos totalitários católicos: efeitos em termos de produção de subjetividade. Estudos de Psicologia (Campinas), 23 (4), 339-358. doi: 10.1590/S0103-166X2006000400003.

Benelli, S. J., \& Costa-Rosa, A. (2010). A construção de redes sociais: entre a conexão e a captura na gestão dos riscos sociais. In E. P. Constantino (Org.), Psicologia, estado e políticas públicas (pp.25-85). Assis: Unesp.

Bock, A. M. B., Gonçalves, M. G., \& Furtado, O. (Orgs.). (2002). Psicologia sócio-histórica: uma perspectiva crítica em psicologia. São Paulo: Cortez.

Borgheti, R. S. (2007). Limites e possibilidades de uma alternativa de educação: análise do projeto Barracão da Cáritas Diocesana de Marília. Dissertação de mestrado não-publicada, Faculdade de Filosofia e Ciências, Universidade Estadual Paulista Júlio de Mesquita Filho.

Brasil. (1984). Código de menores. Brasília: Senado Federal.

Brasil. (1990). Estatuto da criança e do adolescente. Lei no. 8.069 de 1990. Recuperado em março 10, 2008, disponível em <http://www.planalto.gov.br/ccivil/Leis/L80 69.htm>

Brasil. (1993). Lei Orgânica da Assistência Social. no 8.742/ 93. Recuperado em março 10, 2008, disponível em $<$ http://www.mds.gov.br/cnas/legislacao/leis >.

Brasil. (2004). Política nacional de assistência social. Recuperado em março 10, 2008, disponível em <http:// www.mds.gov.br/cnas/legislacao/leis>.

Brasil. (2005). Norma operacional básica do sistema único de assistência social. Recuperado em março 10, 2008, disponível em <http://www.mds.gov.br/cnas/politicae-nobs>.

Bujes, M. I. (2000). O fio e a trama: as crianças nas malhas do poder. Educação \& Realidade, 4 (1), 25-44.

Bujes, M. I. (2002). A invenção do eu infantil: dispositivos pedagógicos em ação. Revista Brasileira de Educação, 21(4), 17-39.
Bulcão, I. (2002). A produção de infâncias desiguais: uma viagem na gênese dos conceitos 'criança' e 'menor'. In M. L. Nascimento (Org.), Pivetes: a produção de infâncias desiguais (pp.61-73). Rio de Janeiro: Oficina do Autor.

Centro de Referência Técnica em Psicologia e Políticas Públicas. (2007). Referência técnica para atuação do(a) psicólogo(a) no CRAS/SUAS. Brasília: CFP.

César, M. R. A. (2008). A invenção da adolescência no discurso psicopedagógico. São Paulo: Unesp.

Coimbra, C. C., Bocco, F., \& Nascimento, M. L. (2005). Subvertendo o conceito de adolescência. Arquivos Brasileiros de Psicologia, 57 (1), 2-11.

Collares, C. A. L., \& Moyses, M. A. A. (1996). Preconceitos no cotidiano escolar:ensino emedicalização. São Paulo: Cortez.

Conselho Federal de Psicologia. (2003). Relatório: políticas públicas, psicologia e protagonismo social. Anais do /l Seminário de Psicologia e Políticas Públicas. João Pessoa.

Conselho Federal de Psicologia. (2005). Identidade profissional e políticas públicas: o diálogo corporativo com o Estado. Anais do Ill Seminário Nacional de Psicologia e Políticas Públicas. Salvador.

Conselho Federal de Psicologia. (2007a). Anais do IV Seminário Nacional de Psicologia e Políticas Públicas. Maceió.

Conselho Federal de Psicologia. (2007b). Do discurso do compromisso social à produção de referências para a prática: construindo o projeto coletivo da profissão. Anais do VI Congresso Nacional da Psicologia. Caderno de deliberações. Brasília.

Conselho Federal de Serviço Social. (2007). Parâmetro para atuação de assistentes sociais e psicólogos(as) na Política de Assistência Social/Conselho Federal de Psicologia (CFP), Conselho Federal de Serviço Social (CFESS). Brasília: Autor.

Costa, A. C. G. (2006). Parâmetros para formação do socioeducador: uma proposta inicial para reflexão e debate. Brasília: Secretaria Especial dos Direitos Humanos.

Costa, C. R. B. S. F., \& Assis, S. G. (2006). Fatores protetivos a adolescentes em conflito com a lei no contexto socioeducativo. Psicologia \& Sociedade, 18 (3), 74-81.

Costa-Rosa, A. (2000). O Modo psicossocial: um paradigma das práticas substitutivas ao modo asilar. In P. D. C. Amarante (Org.), Ensaios de loucura \& civilização (pp.141-168). Rio de Janeiro: Fiocruz.

Costa-Rosa, A. (2006). A Instituição de saúde mental como dispositivo de produção de subjetividade. Manuscrito não-publicado, Universidade Estadual Júlio de Mesquita Filho, Assis.

Cotrim, G. (1993). Educação para uma escola democrática: história e filosofia da educação. São Paulo: Saraiva.

Cruz, L. R., \& Guareschi, N. (2004). Sobre a psicologia no contexto da infância: da psicopatologização à inserção política. Aletheia 20 (2), 77-90.

Cruz, L. R., \& Guareschi, N. (Orgs.). (2009). Políticas públicas e assistência social: diálogo com as práticas psicológicas. Petrópolis: Vozes. 
Cruz, L., Hillesheim, B., \& Guareschi, N. (2005). Infância e políticas públicas: um olhar sobre as práticas psi. Psicologia \& Sociedade 17 (3), 42-49.

Deleuze, G. (1992). Conversações. Rio de Janeiro: Ed. 34.

Diniz, A., \& Lobo, A. P. (Orgs.). (1998). A criança eo adolescente em situação de risco em debate. Rio de Janeiro: LitterisKroArt.

Donzelot, J. (2001). A polícia das famílias. Rio de Janeiro: Graal.

Dreyfus, H., \& Rabinow, P. (1995). Michel Foucault, uma trajetória filosófica: para além do estruturalismo e da hermenêutica. Rio de Janeiro: Forense.

França, S. A. M., Rocha, L. C., Cruz, S. G. P., Justo, J. S., \& Cardoso Jr., H. R. (2004). Estratégias de controle social: errância-criminalização-gestão de risco. São Paulo: Arte \& Ciência.

Ferreiro, E., \& Teberosky, A. (1985). Psicogênese da língua escrita. Porto Alegre: Artes Médicas.

Ferreiro, E., \& Teberosky, A. (1986). Reflexões sobre a alfabetização. São Paulo: Cortez.

Foucault, M. (1999). Vigiar e punir: nascimento da prisão. Petrópolis: Vozes.

Francisco Filho, G. (2004). Panorâmica das tendências e práticas pedagógicas. Campinas: Átomo.

Freitas, M. C. (Org). (1997). História social da infância no Brasil. São Paulo: Cortez.

Gallo, S. (1997). Repensar a educação: Foucault. Filosofia, Sociedade e Educação, 1 (1), 93-118.

Gobitta, M., \& Guzzo, R. S. L. (2002). Estudo inicial do Inventário de Auto-Estima (SEI) Forma A. Psicologia: Reflexão e Crítica, 15 (1), 143-150.

Goffman, E. (1987). Manicômios, prisões e conventos. São Paulo: Perspectiva.

Guimarães, A. M. (1985). Vigilância, punição e depredação escolar. Campinas: Papirus.

Guirado, M. (1986). Instituição e relações afetivas: o vínculo com o abandono. São Paulo: Summus.

Ito, P. C. P., Gobitta, M., \& Guzzo, R. S. L. (2007). Temperamento, neuroticismo e auto-estima: estudo preliminar. Estudos de Psicologia (Campinas), 24 (2), 143-153. doi: 10.1590/S0103-166X2007000200001.

Lakatos, E. M. (1990). Sociologia geral. São Paulo: Atlas.

Lemos, F. C. S. (2008). A educação como dispositivo de proteção à crianças e adolescentes segundo práticas do UNICEF: problematizações foucaultianas. Estudos e Pesquisas em Psicologia (Rio de Janeiro), 8 (3), 559-577.

Libâneo, J. C. (1994). Tendências pedagógicas na prática escolar. In: C. C. Luckesi. Filosofia da educação (pp.53-74). São Paulo: Cortez.

Lourau, R. (1995). A análise institucional. Petrópolis: Vozes.

Marcílio, M. L. (1998). Filhos de ninguém: história social da criança abandonada. São Paulo: Hucitec.

Marcílio, M. L. (2000). O menor infrator e os direitos da 562 criança no século XX. In: M. C. F. Lourenço (Org.), Direitos humanos em dissertações e teses da USP: 1954-1999 (pp.39-49). São Paulo: EDUSP.

Marriel, L. C., Assis, S. G., Avanci, J. Q., \& Oliveira, R. V. C. (2006). Violência escolar e auto-estima de adolescentes. Cadernos de Pesquisa, 36 (127), 35-50.

Martins, C. F., \& Brito, L. M. T. (2001). Resgatando a história da política de atendimento ao adolescente em conflito com a Lei no Brasil. In A. M. Jacó-Vilela, A. C. Cerezzo \& H. B. C. Rodrigues (Orgs.), Clio-Psyché ontem: fazeres e dizeres psi na história do Brasil (pp. 243-248). Rio de Janeiro: Relume Dumará.

Merisse, A. (1996). Ainfância eseus lugares:umestudo sobre as concepções de mães e funcionários de creches. Tese de doutorado não-publicada, Instituto de Psicologia, Universidade de São Paulo.

Montaño, C. E. (2007). Terceiro setor e questão social: crítica ao padrão emergente de intervenção social. São Paulo: Cortez.

Monteiro, L. O. (2006). A judicialização dos conflitos de adolescentes infratores: solução ou mito? Katálysis, 9 (1), 63-74.

Morais, N. A., Leitão, H. S., Koller, S. H., \& Campos, H. R. (2004). Notas sobre a experiência de vida num internato: aspectos positivos e negativos para o desenvolvimento dos internos. Psicologia em Estudo, 9 (3), 379-387.

Moyses, M. A. A., \& Collares, C. A. L. (1992). A história não contada dos distúrbios de aprendizagem. Cadernos CEDES, 28, 31-47.

Nogueira Neto, W. (2010). Enfrentado as diversas formas de violação dos direitos de crianças e adolescente, a partir de um sistema de promoção e de proteção dos direitos humanos de crianças e adolescentes. Recuperado em julho, 2010, disponível em <http://serv01.informacao.andi.org.br/-c4ff3 79_111b38a50b9_-7fb8.pdf>.

Oliveira, M. K. (1993). Vygotsky: aprendizado e desenvolvimento, um processo sócio-histórico. São Paulo: Scipione.

Paiva, I. L., \& Yamamoto, O. H. (2010). Formação e prática comunitária do psicólogo no âmbito do "terceiro setor". Estudos de Psicologia (Natal), 15 (2), 153-160.

Pagni, P. A. (2010). Infância, arte de governo pedagógica e cuidado de si. Educação \& Realidade, 35 (3), 99-123.

Patto, M. H. S. (1984). Psicologia e ideologia. São Paulo: T.A. Queiróz.

Patto, M. H. S. (1990). A produção do fracasso escolar. São Paulo: T.A. Queiróz.

Patto, M. H. S. (1997). Para uma crítica da razão psicométrica. Psicologia USP, 8 (1), 47-62.

Pinheiro, A. A. A. (2004). A criança e o adolescente, representações sociais e processo constituinte. Psicologia em Estudos, 9 (3), 343-355.

Rizzini, I. (1997). O século perdido: raízes históricas das políticas públicas para a infância no Brasil. Rio de Janeiro: Ed. Universitária Santa Úrsula.

Rocha, M. L. (2006). Psicologia e as práticas institucionais: a pesquisa-intervenção em movimento. Psico, 37 (2), 169-174. 
Saliba, M. G. (2006). O olho do poder: análise crítica da proposta educativa do estatuto da criança e do adolescente. São Paulo: Unesp.

Santana, J. P., Doninelli, T. M., Frosi, R. V., \& Koller, S. H. (2004). Instituições de atendimento a crianças e adolescentes em situação de rua. Psicologia \& Sociedade, 16 (2), 59-70.

Santos, B. S. (2000). A crítica da razão indolente: contra o desperdício da experiência. São Paulo: Cortez.

Santos, B. S. (2001). Pela mão de Alice: o social e o político na pós-modernidade. São Paulo: Cortez.

Santos, B. S. (2002). Democratizar a democracia: os caminhos da democracia participativa. Rio de Janeiro: Civilização Brasileira.

Santos, B. S. (2004). Conhecimento prudente para uma vida decente: um discurso sobre as ciências revisitado. São Paulo: Cortez.

Saviani, D. (1988). Escola e democracia: teorias da educação, curvatura da vara, onze teses sobre educação e política. São Paulo: Cortez.

Scherer, C. (2009). O processo de implementação do Sistema Único de Assistência Social no Município de Entre-ljuís/ RS junto à proteção integral das crianças e Adolescentes. Textos \& Contextos, 8 (2), 274-292.
Siqueira, A. C., \& Dell'Aglio, D. D. (2006). O impacto da institucionalização na infância e na adolescência: uma revisão de literatura. Psicologia \& Sociedade, 18 (1), 71-80.

Souza, A. M. (2006). Educação empreendedora: que discurso é esse? Educativa, 9 (2), 217-229.

Tassara, E. T. O. (2004). Avaliação de projetos sociais: uma alternativa política de inclusão? In L. Souza \& Z. A. Trindade (Orgs.), Violênciae exclusão convivendo com paradoxos (pp.75-104). São Paulo: Casa do Psicólogo.

Tuleski, S. C., \& Eidt, N. (2007). M. Repensando os distúrbios de aprendizagem a partir da psicologia histórico-cultural. Psicologia em Estudo, 12 (3), 531-540.

Vygotsky, L. S. (1988). A formação social da mente: o desenvolvimento dos processos psicológicos superiores. São Paulo: Martins Fontes.

Weisz, T. (1987). Como se aprende a ler e a escrever ou prontidão: um problema mal colocado. In São Paulo (Estado). Secretaria da Educação. Ciclo básico (pp.63-83). São Paulo: CENP.

Recebido em: 16/9/2009

Versão final reapresentada em: 23/5/2011

Aprovado em: 1/6/2011 